\title{
The nutritional status of children living within institutionalized care: a systematic review
}

\author{
Emily DeLacey ${ }^{\text {Corresp., } 1,2,3}$, Cally Tann ${ }^{3,4,5,6}$, Nora Groce ${ }^{7}$, Maria Kett ${ }^{7}$, Michael Quiring ${ }^{2}$, Ethan Bergman ${ }^{8}$, Caryl $^{2}$ \\ Garcia $^{2}$, Marko Kerac ${ }^{1,3}$ \\ ${ }^{1}$ Department of Population Health, Faculty of Epidemiology and Population Health, London School of Hygiene \& Tropical Medicine, University of London, \\ London, United Kingdom \\ 2 Holt International, Eugene, Oregon, United States \\ ${ }^{3}$ Centre for Maternal, Adolescent, Reproductive, \& Child Health (MARCH), London School of Hygiene \& Tropical Medicine, University of London, London, \\ United Kingdom \\ 4 Department of Infectious Disease Epidemiology, Faculty of Epidemiology \& Population Health, London School of Hygiene \& Tropical Medicine, University \\ of London, London, United Kingdom \\ 5 MRC/UVRI \& LSHTM Uganda Research Unit, London School of Hygiene \& Tropical Medicine, University of London, Entebbe, Uganda \\ 6 Neonatal Medicine, University College London Hospitals NHS Trust, London, United Kingdom \\ 7 UCL International Disability Research Centre, Department of Epidemiology and Health Care, University College London, London, United Kingdom \\ 8 Department of Health Sciences, College of Education and Professional Studies, Central Washington University, Ellensburg, Washington, United States \\ Corresponding Author: Emily DeLacey \\ Email address: emilyd@holtinternational.org
}

Background. There are an estimated 2.7 million children living within institutionalized care worldwide. This review aimed to evaluate currently available data on the nutrition status of children living within institutionalized care.

Methods. We searched four databases (Pubmed/Medline, CINHAL Plus, Embase and Global Health Database) for relevant articles published from January 1990 to February 2019. Studies that included information on anthropometry or micronutrient status of children living within institutionalized care were eligible for inclusion. The review is registered on PROSPERO: CRD42019117103.

Results. From 3,602 titles screened, we reviewed 98 full texts and 25 papers were eligible. Two (8\%) studies reported data from multiple countries, nine (36\%) were from Asia, four (16\%) from Africa, three (12\%) from Eastern Europe, four (16\%) from the European Union and one (4\%) from each of the remaining regions (Middle East, South America and the Caribbean). Twenty-two (88\%) were cross sectional. Ten (40\%) of the studies focused on children $>5$ years, seven $(28 \%)$ on children $<5$ years, seven $(28 \%)$ covered a wide age range and one did not include ages. Low birth weight ranged from $25-39 \%$. Only five (20\%) included information on children with disabilities reporting prevalence from 8-70\%. Prevalence of undernutrition varied between ages, sites and countries: stunting ranged from 9-72\%; wasting from 0-27\%; underweight from 7-79\%; low BMI from 5-27\%. Overweight/obesity ranged from $10-32 \%$ and small head circumference from $17-41 \%$. The prevalence of HIV was between $2-23 \%$ and anemia from 3-90\%. Skin conditions or infections ranged between $10-31 \%$ and parasites from $6-76 \%$. Half the studies with dietary information found inadequate intake or diet diversity. Younger children were typically more malnourished than older children, with a few exceptions. Institution-based children were more malnourished than community peers, although community children were also often below growth standards. High risk of bias was found.

Conclusions. This study highlights the limited amount of evidence-based data available on the Peer) reviewing PDF | (2019:06:38892:2:0:NEW 11 Dec 2019) 
nutritional status of children in institutions. Of the studies reviewed, children living within institutionalized care were commonly malnourished, with undernutrition affecting young children particularly.

Micronutrient deficiencies and obesity were also prevalent. Data quality was often poor: as well as suboptimal reporting of anthropometry, few looked for or described disabilities, despite this being common in this population and having a large potential impact on nutrition status. Taken together, these findings suggest a need for greater focus on improving nutrition for younger children, especially those with disabilities. More information about children's nutrition status is needed to support the millions of children living within institutionalized care to fully address their right and need for healthy development. 


\section{The nutritional status of children living within institutionalized care: a}

2 systematic review

3 Emily DeLacey ${ }^{1,2,3}$, Cally Tann ${ }^{3,4,5,6}$, Nora Groce ${ }^{7}$, Maria Kett ${ }^{7}$, Michael Quiring ${ }^{2}$, Ethan

4 Bergman $^{8}$, Caryl Garcia ${ }^{2}$, Marko Kerac $^{1,3}$

$5{ }^{1}$ Department of Population Health, Faculty of Epidemiology and Population Health, London

6 School of Hygiene \& Tropical Medicine, University of London; London, United Kingdom

$7 \quad{ }^{2}$ Holt International; Eugene, Oregon, United States of America

$8{ }^{3}$ Centre for Maternal, Adolescent, Reproductive, \& Child Health (MARCH), London School of

9 Hygiene \& Tropical Medicine, University of London; London, United Kingdom

${ }^{4}$ Department of Infectious Disease Epidemiology, Faculty of Epidemiology \& Population Health,

Kingdom

${ }^{5}$ MRC/UVRI \& LSHTM Uganda Research Unit, London School of Hygiene \& Tropical

Medicine, University of London; Entebbe, Uganda

${ }^{6}$ Neonatal Medicine, University College London Hospitals NHS Trust, London; United Kingdom

${ }^{7}$ UCL International Disability Research Centre, Department of Epidemiology and Health Care, University College London; London, United Kingdom

${ }^{8}$ Department of Health Sciences, College of Education and Professional Studies, Central

Washington University; Ellensburg, Washington, United States of America

*Corresponding author:

Emily DeLacey ${ }^{1,2,3}$

Holt International, 250 Country Club Road, Eugene, Oregon, 97402, United States of America 


\section{Abstract}

Background. There are an estimated 2.7 million children living within institutionalized care worldwide. This review aimed to evaluate currently available data on the nutrition status of children living within institutionalized care.

Methods. We searched four databases (Pubmed/Medline, CINHAL Plus, Embase and Global Health Database) for relevant articles published from January 1990 to February 2019. Studies that included information on anthropometry or micronutrient status of children living within institutionalized care were eligible for inclusion. The review is registered on PROSPERO: CRD42019117103.

Results. From 3,602 titles screened, we reviewed 98 full texts and 25 papers were eligible. Two $(8 \%)$ studies reported data from multiple countries, nine $(36 \%)$ were from Asia, four (16\%) from Africa, three (12\%) from Eastern Europe, four (16\%) from the European Union and one (4\%) from each of the remaining regions (Middle East, South America and the Caribbean). Twentytwo $(88 \%)$ were cross sectional. Ten $(40 \%)$ of the studies focused on children $>5$ years, seven $(28 \%)$ on children $<5$ years, seven $(28 \%)$ covered a wide age range and one did not include ages. Low birth weight ranged from 25-39\%. Only five (20\%) included information on children with disabilities reporting prevalence from 8-70\%. Prevalence of undernutrition varied between ages, sites and countries: stunting ranged from $9-72 \%$; wasting from $0-27 \%$; underweight from $7-79 \%$; low BMI from 5-27\%. Overweight/obesity ranged from 10-32\% and small head circumference from $17-41 \%$. The prevalence of HIV was between $2-23 \%$ and anemia from $3-90 \%$. Skin conditions or infections ranged between $10-31 \%$ and parasites from 6-76\%. Half the studies with dietary information found inadequate intake or diet diversity. Younger children were typically more malnourished than older children, with a few exceptions. Institution-based children were more malnourished than community peers, although community children were also often below growth standards. High risk of bias was found.

Conclusions. This study highlights the limited amount of evidence-based data available on the nutritional status of children in institutions. Of the studies reviewed, children living within institutionalized care were commonly malnourished, with undernutrition affecting young children particularly. Micronutrient deficiencies and obesity were also prevalent. Data quality was often poor: as well as suboptimal reporting of anthropometry, few looked for or described disabilities, despite this being common in this population and having a large potential impact on nutrition status. Taken together, these findings suggest a need for greater focus on improving nutrition for younger children, especially those with disabilities. More information about children's nutrition status is needed to support the millions of children living within institutionalized care to fully address their right and need for healthy development. 


\section{Introduction}

Malnutrition impacts millions of children around the world (Black et al. 2013; The World Bank Group; UNICEF April 2019). In 2018 for children younger than 5 years old, 49 million children were wasted, just under one in four $(21.9 \%)$ were stunted and $5.9 \%$ were overweight (UNICEF April 2019). Almost half of the deaths among children younger than 5 years old have undernutrition as an underlying factor (Black et al. 2013; UNICEF April 2019). In some countries, up to half of adolescents are stunted, as many as $11 \%$ are too thin, up to $5 \%$ are obese and over 50\% are anemic (Black et al. 2013). Being malnourished has many adverse consequences including increased risk and severity of infections, increased risk of disability, and death (Black et al. 2013; Groce et al. 2014; McDonald et al. 2013; Myatt et al. 2018). This can be a part of a cyclical interaction between infections and undernutrition which leads to poor nutritional status, illnesses and impacted growth. The first 1,000 days of a child's life are particularly important because poor nutrition at this stage also predisposes children to long-term impairments such as stunted growth, impaired cognition and poor performance at school and work (Black et al. 2013; UNICEF April 2019).

Some children are at higher risk of malnutrition, such as orphans and children living within institutionalized care (UNICEF April 2019). UNICEF estimates that there are some 140 million orphans worldwide who have lost either one or both of their parents (UNICEF 2017). Although most orphans live with other family members, some live in institutionalized care or residential care facilities (UNICEF 2017). Institutionalized care is defined by the United Nations as residential care that is provided in any non-family-based group setting, including all other shortand long-term residential care facilities (United Nations General Assembly 2009). Many nonorphans live in institutionalized care for a variety of reasons, such as social or economic (Marinus H van IJzendoorn 2011; The Children's Health Care Collaborative Study Group 1994). These children are also vulnerable (Baron et al. 2001; The Children's Health Care Collaborative Study Group 1994). Though family-based care is the ideal environment for all children, this is not always possible (Petrowski et al. 2017; The Children's Health Care Collaborative Study Group 1994).

Approximately 2.7 million children ages 17 years and younger live in residential care globally: 120 children per 100,000 (Petrowski et al. 2017). The UN Convention on the Rights of the Child states that when it is in a child's best interest and they cannot remain in their family, alternativecare options need to be provided for the child. Alternative-care solutions include foster care or institutional care. These alternative-care options need to meet a standard of living adequate for a child's full development, including children with disabilities; particularly in regard to education, health, development, nutrition and other essentials (United Nations Human Rights Office of the High Commissioner 1990).

Children in institutional care often face numerous adversities prior to admission and many enter institutionalized care with pre-existing nutritional, developmental, medical and neurological conditions (Baron et al. 2001; The Children's Health Care Collaborative Study Group 1994; The St. Petersburg-USA Orphanage Research Team 2005; The St. Petersburg-USA Orphanage Research Team 2008). Some have disabilities or were born prematurely or with low birth weight 
103

104

105

106

107

108

109

110

111

112

113

114

115

116

117

118

119

120

121

122

123

124

125

and many have had exposure to drugs or alcohol, HIV, stress or a range of other issues - all of which can impact their health. (Baron et al. 2001; Groce et al. 2014; The Children's Health Care Collaborative Study Group 1994; The St. Petersburg-USA Orphanage Research Team 2008). Often there is limited or no information about children's early lives or exposures prior to coming into care (The Children's Health Care Collaborative Study Group 1994; The St. Petersburg-USA Orphanage Research Team 2005; The St. Petersburg-USA Orphanage Research Team 2008). Those entering institutionalized care may experience further negative issues when admitted: ongoing risk of suboptimal nutrition, poor growth or growth failure, neglect or abuse, impacted physical and mental development, diarrhea, anemia, infections and diseases because of the conditions in the care centers (Frank et al. 1996; Johnson \& Gunnar 2011; The Children's Health Care Collaborative Study Group 1994). Disability can be both a contributing factor and a result of malnutrition. In addition, disabilities, micronutrient deficiencies and malnutrition can all lead to increased morbidities and mortality (Groce et al. 2014; McDonald et al. 2013; Myatt et al. 2018).

Often because of limited staffing, time and fiscal constraints, institutions are able to only provide basic care needs for children instead of addressing children's individual needs for healthy and full development (Marinus H van IJzendoorn 2011; Whetten et al. 2014). Factors impacting children's nutrition status in care centers include inadequate or poor quality of food or inappropriate types of food; inadequate stimulation or attention; improper use of medications; inappropriate feeding practices; and poor hygiene and sanitation leading to frequent illnesses and negatively impacting utilization of nutrients (Frank et al. 1996; Marinus H van IJzendoorn 2011; The St. Petersburg-USA Orphanage Research Team 2008). 
127

128

129

130

131

132

133

134

135

136

137

138

139

140

141

142

143

144

145

146

147

148

149

150

151

152

153

154

155

156

157

158

159

160

161

162

163

164

165

166

\section{Methods}

The aim of our review was to better understand the current nutritional status of children in care by looking at anthropometric and nutritional status indicators in relation to age, disability, geography, gender and related factors, with an ultimate goal of improving policy and practice to better meet the needs of this unique and vulnerable population.

We analyzed existing published peer-reviewed literature on nutrition status of children in institutional care by examining anthropometric data and micronutrient status and other factors including disability status, gender and age. PRISMA guidelines were followed throughout the review process and a PROSPERO registration was completed prior to the start of the study (PROSPERO 2019: CRD42019117103, https://www.crd.york.ac.uk/PROSPERO/display_record.php?RecordID=117103 ) (Moher et al. 2009; National Institute for Health Research 2019).

The review primarily evaluated observational and intervention studies. Inclusion criteria included material which was published between January 1990 and January 2019 in English and contained research related to orphanages/institutionalized care, children, nutrition, anthropometric data or micronutrient status. We selected these dates because the Convention on the Rights of the Child went into effect in 1990, and since then, there have been significant changes in institutional care and changes in the understanding of the needs of children in institution-based care (IBC) (Frank et al. 1996; United Nations Human Rights Office of the High Commissioner).

In order to be included in this review, the studies must have addressed a population of children younger than 18 years old (with the exception of one study which included children as old as 20 years but was retained for informational value), been peer reviewed and included at least one measurement of nutrition status through standardized tools, such as WHO Growth Standards or WHO Growth References and definitions (World Health Organization 2019a; World Health Organization 2019b). Anthropometric indicators of interest included: weight for age, length/height for age, weight for length/height, head circumference for age and mid-upper arm circumference for age. Micronutrient status, clinical signs/symptoms and dietary information was also included when available. Emily DeLacey, the principal investigator, and Dr. Marko Kerac determined and used the search strategy. Four electronic databases were searched through OVID from December 2018 through January 2019: Pubmed/Medline, CINHAL Plus, Embase and Global Health Database. For details of our search strategy, see Appendix 1. Initial article screening was based on title and abstract, following which, full texts were assessed for eligibility against our pre-specified inclusion/exclusion criteria. Discussions with the research team resolved any questions of eligibility with Dr. Cally Tann deciding any discords. A data extraction table was used to summarize key information from the final selection of articles into tables and columns organized by related themes and areas.

Nutritional status was determined according to reported anthropometry, whether reported by zscores (standard deviations from a reference population), or percentiles. Micronutrient status and intake was also reported on and included prevalence of anemia or micronutrient deficiencies. Other key data areas included disability status, birth weight, sex, age, dietary intake and any 
167 reported disease, illness or infection which could impact nutrition status. Heterogeneity in the

168 type of interventions prevented our ability to conduct a meta-analysis of the study, so a narrative 169 synthesis was used.

170 
171

172

173

174

175

176

177

178

179

180

181

182

183

184

185

186

187

188

189

190

191

192

193

194

195

196

197

198

199

200

201

202

203

204

205

206

207

208

209

210

\section{Results}

We found a total of 3,973 papers. After 371 duplicates were removed, the remaining 3,602, were screened by title and abstract. All but 98 articles were excluded during this phase. Of the 98 identified as potentially eligible, we were unable to locate seven, 53 had insufficient anthropometry or used non-standard measurements, 10 did not have appropriate population or study type and three were excluded because the anthropometric data existed in another study. Twenty-five studies met our inclusion criteria (Figure 1). Most studies (22, 88\%) were cross sectional (Table 1). The most commonly researched region was Asia with nine studies (36\%), followed by Africa with four studies (16\%). Three (12\%) were from Eastern Europe, four (16\%) from the European Union and one (4\%) from each of the remaining regions (Middle East, South America and the Caribbean). Kenya and India were the most commonly researched countries and were each included in four studies (Table 1). Ten (40\%) focused on children older than 5 years, seven $(28 \%)$ on children younger than 5 years, seven $(28 \%)$ covered a wide age range and one did not include ages. Twelve (48\%) included control or comparison groups of children who were community children (CC) or orphaned, separated or abandoned children living in family-based care (FBC), or children living on the streets (CLS). Control groups were typically orphaned children living in family-based care (FBC) or community children (CC) with no history of institutional care and the groups were selected from different settings including from local schools, communities, clinics or hospitals, lists, house-to-house census or other child-related programs (Braitstein et al. 2013; Johnson et al. 2010; Whetten et al. 2014). Eight (32\%) studies mentioned or analyzed gender differences (Table 1 and 2). A history of low birth weight (LBW) was also common (25\% to $39 \%)$.

\section{Children with Disabilities}

Of the 25 studies reviewed, 12 (48\%) did not state whether they included children with disabilities (Table 1 and 2). Eight (32\%) of the studies stated that children with disabilities were excluded, leaving only five (20\%) mentioning children with disabilities in their reporting, but either excluded them from analysis or did not state whether or not they were excluded. Only one study included any anthropometric measurements for children with disabilities (Lewindon et al. 1997). The St. Petersburg-USA Orphanage Research Team found that $21 \%$ of children had disabilities (The St. Petersburg-USA Orphanage Research Team 2005). Miller and colleagues found $16 \%$ of institution-based children (IBC) had significant disabilities and $70 \%$ had developmental delays (Miller et al. 2006).

\section{Anthropometrics}

Undernutrition, micronutrient deficiencies and overweight/obesity were reported in varying ways. Prevalence of undernutrition differed markedly: stunting (low length/height for age) from 9 to $72 \%$; wasting (low weight for length/height) from 0 to $27 \%$; underweight (low weight for age) from 7 to $79 \%$; low BMI (body mass index) ranged from 5 to $27 \%$ (Table 2). Ten to $32 \%$ of children were overweight or obese. Panpanich et al. found children younger than 5 years old to be more stunted, wasted and underweight than older children and below WHO growth standards (Panpanich et al. 1999). The prevalence of small head circumference ranged from 17 to $41 \%$. 
211

212

213

214

215

216

217

218

219

220

221

222

223

224

225

226

227

228

229

230

231

232

233

234

235

236

\section{$\underline{\text { Micronutrients, clinical signs/symptoms and infections }}$}

Clinical signs or symptoms were reported in $48 \%$ (12) of the studies (Table 3). Five (20\%) mentioned HIV but two of these were conducted in institutions for children with HIV (Kapavarapu et al. 2012; Myint et al. 2012). Excluding the facilities for children with HIV, HIV prevalence was 2 to $23 \%$. One study found a higher prevalence of morbidity among children in IBC than CC ( $\mathrm{p}<0.05)$ (Mwaniki et al. 2014). The prevalence of parasites ranged between 6 to $76 \%$, with Lesho and colleagues finding $10 \%$ of children in IBC having three or more parasites (Lesho et al. 2002). Skin infections, varicella zoster, tuberculosis, impetigo, dental issues, ear/nose/throat problems, respiratory infections, diarrhea and other conditions or illnesses were frequently reported among IBC (Table 3). Skin conditions or infections ranged between 10 to $31 \%$ and Kapavarapu and colleagues found $75 \%$ of children had an infection within the first three months of admission to a site (Kapavarapu et al. 2012). Seven (28\%) reported on micronutrient status or intake and the prevalence of anemia ranged from 3 to $90 \%$. Hearst and colleagues found over a third of children had low vitamin D (Hearst et al. 2014). Other micronutrient deficiencies discussed included iodine, zinc, albumin, as well as vitamins A and B (Table 3). Edema, conjunctival pallor, xerophthalmia and goiters were found more in children in IBC than those living in FBC (Aboud et al. 1991).

\section{Dietary diversity, intake and food security}

Eight (32\%) studies discussed dietary diversity, intake or food security (Table 3). Mwaniki and colleagues found that diet diversity was lower in children living in IBC than for CC $(\mathrm{p}<0.05)$. Diets were reported to have a high reliance on starches and legumes (Mwaniki et al. 2014). Of the studies that assessed dietary intake, $50 \%$ found adequate intake. Dietary adequacy varied; from children in IBC at 3.9 times higher risk of consuming inadequate calories to having $362 \%$ higher intake than estimated average requirements for some nutrients. The one study which reported on food security found that children in IBC had higher food security when compared to children in FBC, $42 \%$ vs. $2 \%$ (Braitstein et al. 2013). 


\section{Discussion}

238 The nutritional status of children living in institutions has the potential to adversely impact their health and well-being, yet out of 3,602 papers from four major databases, only 25 peer-reviewed papers presented evidence based findings on the children's nutrition status (Figure 1). All 25 reviewed studies indicated that many of the children in institutionalized care faced some form of malnutrition. The available data suggests that children living within institutionalized care are commonly malnourished: affected by both undernutrition, overweight and micronutrient deficiencies. With few exceptions, mostly of older children, children living within institutionalized care were significantly below standards for growth, diet and micronutrient status and were often below comparison groups of their community peers. Nutrition status varied between care centers and between the ages of children, with younger children at a higher risk of being malnourished. There may be a number of reasons why this is the case, such as younger children have a harder time feeding themselves, especially if disabilities are present, and young, poorly nourished children are at risk of not surviving to become older children in institutional settings (McDonald et al. 2013; Myatt et al. 2018; The Children's Health Care Collaborative Study Group 1994). Diet inadequacy, micronutrient deficiencies and illnesses or infections were also found to be prevalent in children of all ages.

To our knowledge, this is the first systematic review on the nutrition status of children living within institutionalized care. It is important because 2.7 million children worldwide live in IBC and there are a multitude of factors and reasons why they may be affected by different types of malnutrition. The extent and direction of this has not been well studied nor is it currently being effectively monitored or assessed (Petrowski et al. 2017). Representing an inherently high-risk population, there are many reasons why we would expect undernutrition to be common: this was indeed observed in our review. Conversely, there are some reasons why IBC may offer opportunities for good nutrition and access to services, such as better food security, more reliable funding sources and access to specialized therapy or treatment. These ideal factors may not be possible or available for families affected by different economic circumstances living in the same communities (Braitstein et al. 2013; Panpanich et al. 1999; Whetten et al. 2014).

Our review, which used a comprehensive search strategy, also notably highlights a lack of well reported and standardized evidence. Only 19 countries were represented in our findings, despite Petrowski and colleagues finding 140 countries with data on children in institutions and this limited our ability to determine trends or region-specific patterns and risk factors (Petrowski et al. 2017).

Children with disabilities and children with low birth weight

A key observation is that few studies mentioned children with disabilities and only one included anthropometric analysis (Table 1 and 2) (Lewindon et al. 1997). Children with disabilities are disproportionately present in institutionalized care settings. (Baron et al. 2001; The Children's Health Care Collaborative Study Group 1994; The St. Petersburg-USA Orphanage Research 
277

278

279

280

281

282

283

284

285

286

287

288

289

290

291

292

293

294

295

296

297

298

299

300

301

302

303

304

305

306

307

308

309

310

311

312

313

314

315

316

and/or intake needs. In addition, children with disabilities face the risk of their disabilities worsening in environments that do not meet their individual needs (Groce et al. 2014; Kroupina et al. 2014). Children with some types of disabilities may have higher caloric needs or require specialized diets or additional supports at mealtimes (Groce et al. 2014; Johnson \& Gunnar 2011; Johnson et al. 2010; Kroupina et al. 2014; The Children's Health Care Collaborative Study Group 1994; The St. Petersburg-USA Orphanage Research Team 2008).

Children in care or those who stay in care the longest may have more disabilities, more underlying diseases or more complex backgrounds - including a history of low birth weight (LBW) and therefore may require more focused care (The Children's Health Care Collaborative Study Group 1994; The St. Petersburg- USA Orphanage Research Team 2005). Even when provided with adequate diet and medical care, these groups may be more dependent on caregivers for feeding, or need specialized approaches to feeding such as supportive seating and positioning, adaptive skill development and an extended time to eat (Johnson \& Gunnar 2011). When children enter into care they are often in poor health and those that stay the longest, such as children with disabilities, are frequently in worse condition compared to children who are healthy at admission (Groce et al. 2014, The St. Petersburg-USA Orphanage Research Team 2005). This is all important to highlight because becoming malnourished while living in an institution can also increase the risk of children developing a disability (Groce et al. 2014).

High rates of low birth weight infants in institutions were common; although child history, records or tracking were often limited (Johnson et al. 2010; Kroupina et al. 2014; The Children's Health Care Collaborative Study Group 1994; The St. Petersburg-USA Orphanage Research Team 2005). Health status at birth was found to be a significant determinant of development and growth trajectories and pre- and perinatal circumstances influence children's development in care: nutrition needs vary depending on individual growth rates and the presence of preexisting nutrition deficiencies (Johnson et al. 2010; Kroupina et al. 2014; Martins et al. 2013). Johnson \& Gunnar and Johnson et al. found that during early rapid-growth phases, the effects of even modest nutritional deficits can become magnified (Johnson \& Gunnar 2011; Johnson et al. 2010). Age, age at admission and length of stay were other key factors identified that were associated with nutritional status (Chowdhury et al. 2017; Kroupina et al. 2014; Martins et al. 2013; Panpanich et al. 1999).

\section{Gender and malnutrition}

Gender is also important to consider because programs and policies should be evidence-based and equitable, offering support to those most in need (Theobald et al. 2017). However, our review found that only nine of the studies compared genders. Of these, two found that girls were more malnourished, three found boys were more malnourished than girls and another four found both groups had similarly high prevalence of malnutrition or no significant difference in nutritional status by gender. We thus have mixed and inconclusive evidence of malnutrition or risk of malnutrition being linked to gender of children in institutional care (Table 2). This may be a very context specific issue where social as well as biological factors play a role.

\section{$\underline{\text { Anthropometrics }}$}


317 Frequently the prevalence of low birth weight, stunting, wasting, underweight, anemia, and overweight was higher in IBC compared to the global prevalence for children younger than 5 years old (The World Bank Group). Paralleling global trends, the triple burden of malnutrition also needs to be examined in IBC (Black et al. 2013; UNICEF April 2019). Although only a few studies reported on overweight, when it was reported, the prevalence was high, especially for adolescents. Future studies should report on overweight as well as underweight. A positive feature of the studies reviewed was that many had peer groups for comparison; this is helpful because many children in the surrounding community may also deviate from WHO growth standards and it is helpful to see the nutritional status of children in IBC in local as well as global context. Multiple studies found that children in IBC were more undernourished than community children (CC) or children living in family-based care (FBC) (Table 2). Six studies indicated that peers within the community were more likely to be malnourished than children living within IBC, although this varied a bit by age. This could be in part due to children in care receiving adequate nutrition, routine meals and health screenings, especially for children who have HIV and/or it could reflect the challenges faced by families in those communities (Braitstein et al. 2013; Panpanich et al. 1999; Sarma et al. 1991; Whetten et al. 2014; Whetten et al. 2009; Zahid \& Karim 2013).

\section{Clinical signs/symptoms, micronutrient status and infections}

HIV prevalence was higher than global percentages for the few sites that reported it (The World Bank Group). HIV can be a significant risk factor for becoming malnourished and is also a contributing factor to children ending up in care (Kotler 1989; Leyenaar 2005). Another clear gap was that less than a third reported on the micronutrient status and less than half reported on clinical signs/ symptoms or infections (Table 3). Micronutrient deficiencies were common with a prevalence of anemia higher than the global average in the majority of studies (The World Bank Group). The prevalence of micronutrient deficiencies in children in IBC is likely linked to their increased risk of sickness or morbidities (Black et al. 2013). Hearst et al. concluded that the growth-related indicators coincide with the high prevalence of low albumin, indicating generalized chronic undernutrition and suggests macronutrient deficiencies that could be due to inadequate diets, infections and/or inflammation, or impaired nutrient absorption or utilization secondary to the psychosocial stress of living in an institution (Hearst et al. 2014).

Dietary diversity, intake and food security

Only eight (32\%) studies included information on dietary intake and, of those, half found intake or diet diversity to be inadequate. Dietary diversity was reported to be low for children in IBC, especially in terms of fruits, vegetables and protein. Limited funding and reliance on donations for food were frequently mentioned issues, and resulted in diets high in starches and legumes (Mwaniki et al. 2014). Dietary adequacy varied; in some IBC sites children received an adequate amount or more than recommended dietary allowances and in others they received below the recommendations. Interestingly, the one study which reported on food security found that children in a Kenyan orphanage had higher food security when compared to children in FBC (Braitstein et al. 2013). However, it is impossible to generalize from this one study to say anything more broadly about food security. 
358

359

360

361

362

363

364

365

366

367

368

369

370

371

372

373

374

375

376

377

378

379

380

381

382

383

384

385

386

387

388

389

390

391

392

393

394

395

396

397

398

\section{$\underline{\text { Limitations }}$}

We focused on nutritional status of children living in care but note that many other issues (e.g. development, cognition, puberty, catch-up growth, care practices, length of stay, age at admission, cause of institutionalization, illnesses, health of children who have been adopted or cultural practices) affect the demographics, health and well-being of children who are in institutions. It could be that all children coming into care are at risk due to the adverse events and trauma of being abandoned or orphaned (Baron et al. 2001; Martins et al. 2013; The Children's Health Care Collaborative Study Group 1994; The St. Petersburg-USA Orphanage Research Team 2008). These wider factors were beyond the scope of this study (as well as infrequently reported in sufficient details in papers). Given biological links between poor nutrition and suboptimal child development, evaluating these topics in more depth is critical in future work.

Although we found some research, there was limited recent information on this population of children. This may be because of practical or ethical considerations or it may reflect the desire to move away from institution-based care to family-based living situations for children (Kelley et al. 2016). This review also only analyzed data from January 1990 to January 2019 and the studies were of differing designs and types. The review did not find not enough studies to be able to examine differences between IBC, FBC, CC and CLS (children living on the streets). Other weaknesses included the common use of non-standard reporting methods or lack of clarity around measurement methods, such as how studies assessed micronutrient status or clinical signs and symptoms or determined disability status. Many of the studies were examining other subjects and nutritional/anthropometric information was only supplementary. Furthermore, growth measurements may have been affected by measurement or other errors (e.g. incorrect birthdate estimates leading to incorrect z-score calculations for age-related indices). Additionally, children with some types of disabilities may be shorter or lighter not because of inadequacy of dietary intake but because of their specific underlying conditions (e.g. disabilities such as Down syndrome and many others are associated with non-standard growth and development). It is also possible that there is under-diagnosis or misdiagnosis of medical conditions, chronic diseases or disabilities in these settings, which can also impair the growth and development of children (Byass et al. 2011). Another consideration is the potential for healthy survivor bias and sampling bias: some of the most vulnerable children may have died prior to measurement; younger children and healthier children may more quickly leave institutions with the remaining older residents more likely to have deficiencies (Marinus H van IJzendoorn 2011; The St. PetersburgUSA Orphanage Research Team 2005).

Risk of bias was apparent in most of the studies. We had originally considered using a formal risk of bias tool to differentiate study quality but did not do so because it became apparent that all of the studies had a high risk of bias and could not be representative of all the institutions in the countries. Another concern was that many used convenience sampling. It is also plausible that the sites included in the research were better-off facilities, which welcomed researchers, who were looking to share positive results and good performance. These are unlikely to be representative of all sites; we speculate that the overall situation is likely worse at many facilities with higher prevalence of malnutrition indicators. There is also wide variation between different 
399

400 2014).

\section{Conclusions}

402

403

404

405

406

407

408

409

410

411

412

413

414

415

416

417

418

419 rights initiatives.

institutional care facilities (Marinus H van IJzendoorn 2011; Petrowski et al. 2017; Whetten et al.

A key finding from this study was the limited amount of quality evidence-based data available on the nutritional status of children in institutions. Equally as important, our review found that where data was available, children living in institutionalized care were consistently at high risk of malnutrition, commonly experiencing undernutrition, overweight and/or micronutrient deficiencies. The implications for caregivers, clinicians, institutional administration and policy makers is that work is needed to ensure all children's basic rights to nutrition are met. Children living within care are at risk and require special attention. This is especially true for children with disabilities and low birth weight infants.

Although institutionalized care is not the ideal setting for children to grow up in, living within care continues to be a reality for many children. This study is in agreement with other papers and reports that support optimizing current institutional environments when alternative placements for orphaned or abandoned children are not available. These children have a right to good nutrition, both to maintain their health now and to allow them to grow into healthy adults. Interventions will need to be multifaceted to address all of the root causes of malnutrition faced by children living in care. The need for much more evidence as well as a commitment to monitoring and evaluation of nutritional status in all institutions, should be acknowledged and children supported through improved nutrition programming as part of broader policy and child 


\section{References}

Aboud F, Samuel M, Hadera A, and Addus A. 1991. Intellectual, social and nutritional status of children in an Ethiopian orphanage. Soc Sci Med 33:1275-1280.

Baron AM, Baron YM, and Spencer NJ. 2001. The care and health needs of children in residential care in the Maltese Islands. Child Care Health Dev 27:251-262.

bin Shaziman S, Rani MDM, Aripin KNN, Hamid NA, Sulaiman WNW, Rahman ZA, and Abdullah MY. 2017. Assessing nutritional knowledge, attitudes and practices and body mass index of adolescent residents of orphanage institutions in Selangor and Malacca. Pakistan Journal of Nutrition 16:406-411. http://dx.doi.org/10.3923/pjn.2017.406.411

Black RE, Victora CG, Walker SP, Bhutta ZA, Christian P, de Onis M, Ezzati M, Grantham-McGregor S, Katz J, Martorell R, and Uauy R. 2013. Maternal and child undernutrition and overweight in low-income and middle-income countries. The Lancet 382:427-451. 10.1016/s0140-6736(13)60937-x

Braitstein P, Ayaya S, Nyandiko WM, Kamanda A, Koech J, Gisore P, Atwoli L, Vreeman RC, Duefield C, and Ayuku DO. 2013. Nutritional status of orphaned and separated children and adolescents living in community and institutional environments in uasin gishu county, kenya. PLoS One 8:e70054. 10.1371/journal.pone.0070054

Byass P, Kahn K, and Ivarsson A. 2011. The Global Burden of Childhood Coeliac Disease: A Neglected Component of Diarrhoeal Mortality? PLoS One 6:e22774. 10.1371/journal.pone.0022774

Chowdhury ABMA, Wasiullah S, Haque MI, Muhammad F, Hasan MM, Ahmed KR, and Chowdhury M. 2017. Nutritional status of children living in an orphanage in Dhaka city, Bangladesh. Malays J Nutr 23:291-298.

El-Kassas G, and Ziade F. 2017. The Dual Burden of Malnutrition and Associated Dietary and Lifestyle Habits among Lebanese School Age Children Living in Orphanages in North Lebanon. J Nutr Metab 2017:4863431. 10.1155/2017/4863431

Frank DA, Klass PE, Earls F, and Eisenberg L. 1996. Infants and young children in orphanages: one view from pediatrics and child psychiatry. Pediatrics 97:569-578.

Groce N, Challenger E, Berman-Bieler R, Farkas A, Yilmaz N, Schultink W, Clark D, Kaplan C, and Kerac M. 2014. Malnutrition and disability: unexplored opportunities for collaboration. Paediatr Int Child Health 34:308-314. 10.1179/2046905514Y.0000000156

Hearst MO, Himes JH, Johnson DE, Kroupina M, Syzdykova A, Aidjanov M, and Sharmonov T. 2014. Growth, nutritional, and developmental status of young children living in orphanages in Kazakhstan. Infant Ment Health J 35:94-101. 10.1002/imhj.21430

Johnson DE, and Gunnar MR. 2011. IV. Growth Failure in Institutionalized Children. Monographs for the Society for Research in Child Development, 76:92-126. 10.1111/j.1540-5834.2011.00629.x

Johnson DE, Guthrie D, Smyke AT, Koga SF, Fox NA, Zeanah CH, and Nelson CA, 3rd. 2010. Growth and associations between auxology, caregiving environment, and cognition in socially deprived Romanian children randomized to foster vs ongoing institutional care. Arch Pediatr Adolesc Med 164:507-516. 10.1001/archpediatrics.2010.56

Kapavarapu PK, Bari O, Perumpil M, Duggan C, Dinakar C, Krishnamurthy S, Arumugam K, and Shet A. 2012. Growth patterns and anaemia status of HIV-infected children living in an institutional facility in India. Trop Med Int Health 17:962-971. 10.1111/j.1365-3156.2012.03022.x

Kelley MC, Brazg T, Wilfond BS, Lengua LJ, Rivin BE, Martin-Herz SP, and Diekema DS. 2016. Ethical challenges in research with orphans and vulnerable children: a qualitative study of researcher experiences. Int Health 8:187-196. 10.1093/inthealth/ihw020

Kotler DP. 1989. Malnutrition in HIV infection and AIDS. AIDS 3 Suppl 1:S175-180. 10.1097/00002030198901001-00025Kroupina MG, Toemen L, Aidjanov MM, Georgieff M, Hearst MO, Himes JH, Johnson DE, Miller BS, Syzdykova AM, and Sharmanov TS. 2014. Predictors of developmental status in young children living in institutional care in Kazakhstan. Matern Child Health J 19:1408-1416. 10.1007/s10995014-1647-0

Lesho E, Braun L, Coots N, Ozguc O, Ciobanu M, and Fitzpatrick L. 2002. Disease prevalence among moldovan orphans and other considerations for future humanitarian aid. Clin Pediatr (Phila) 41:235-237.

Lewindon PJ, Lau D, Chan A, Tse P, and Sullivan PB. 1997. Helicobacter pylori in an institution for disabled children in Hong Kong. Dev Med Child Neurol 39:682-685.

Leyenaar JK. 2005. HIV/AIDS and Africa's orphan crisis. Paediatrics and Child Health 10:259-260.

Marinus H van IJzendoorn JP, Edmund Barke, Megan R Gunnar, Panayiota Vorria, Robert B McCall, Lucy Le Mare, Marian J Bakermans-Kranenburg, Natasha A Dobrova-Krol and Femmie Juffer. 2011. Children in 
institutional care: delayed development and resilience. Monographs for the Society for Research in Child Development, 76:8 - 30. 10.1111/j.1540-5834.2011.00626.x

Martins C, Belsky J, Marques S, Baptista J, Silva J, Mesquita AR, de Castro F, Sousa N, and Soares I. 2013. Diverse physical growth trajectories in institutionalized Portuguese children below age 3: relation to child, family, and institutional factors. J Pediatr Psychol 38:438-448. 10.1093/jpepsy/jss129

McDonald CM, Olofin I, Flaxman S, Fawzi WW, Spiegelman D, Caulfield LE, Black RE, Ezzati M, Danaei G, and Nutrition Impact Model S. 2013. The effect of multiple anthropometric deficits on child mortality: metaanalysis of individual data in 10 prospective studies from developing countries. Am J Clin Nutr 97:896-901. 10.3945/ajcn.112.047639

Miller LC, Chan W, Litvinova A, Rubin A, Comfort K, Tirella L, Cermak S, Morse B, and Kovalev I. 2006. Fetal alcohol spectrum disorders in children residing in Russian orphanages: a phenotypic survey. Alcohol Clin Exp Res 30:531-538. 10.1111/j.1530-0277.2006.00059.x

Moher D, Liberati A, Tetzlaff J, Altman DG, and Group P. 2009. Preferred reporting items for systematic reviews and meta-analyses: the PRISMA statement. J Clin Epidemiol 62:1006-1012. 10.1016/j.jclinepi.2009.06.005

Mwaniki EW, Makokha AN, and Muttunga JN. 2014. Nutrition status of children in orphanages in selected primary schools within Dagoretti Division Nairobi, Kenya. East Afr Med J 91:289-297.

Myatt M, Khara T, Schoenbuchner S, Pietzsch S, Dolan C, Lelijveld N, and Briend A. 2018. Children who are both wasted and stunted are also underweight and have a high risk of death: a descriptive epidemiology of multiple anthropometric deficits using data from 51 countries. Arch Public Health 76:28. 10.1186/s13690018-0277-1

Myint K, Aye MTH, Moe S, and Kyaw S. 2012. Ocular and other comorbidities in HIV positive orphans in Myanmar. International Journal of Collaborative Research on Internal Medicine and Public Health 4:1245-1256.

National Institute for Health Research. 2019. PROSPERO International prospective register of systematic reviews. https://www.crd.york.ac.uk/prospero/: University of York Centre for Reviews and Dissemination

Panpanich R, Brabin B, Gonani A, and Graham S. 1999. Are orphans at increased risk of malnutrition in Malawi? Ann Trop Paediatr 19:279-285.

Petrowski N, Cappa C, and Gross P. 2017. Estimating the number of children in formal alternative care: Challenges and results. Child Abuse Negl 70:388-398. 10.1016/j.chiabu.2016.11.026

Pysz K, Leszczynska T, and Kopec A. 2015. Anthropometric assessment of the nutritional status of children and adolescents residing in selected Polish orphanages based on their energy intake and physical activity level. Rocz Panstw Zakl Hig 66:77-83.

Sarma KV, Vazir S, Rao DH, Sastry JG, and Rao NP. 1991. Nutrition, health and psychosocial profile of institutionalized children. Indian Pediatr 28:767-778.

Smyke AT, Koga SF, Johnson DE, Fox NA, Marshall PJ, Nelson CA, and Zeanah CH. 2007. The caregiving context in institution-reared and family-reared infants and toddlers in Romania. J Child Psychol Psychiatry 48:210218. 10.1111/j.1469-7610.2006.01694.x

The Children's Health Care Collaborative Study Group. 1994. The causes of children's institutionalization in Romania. Child Care Health Dev 20:77-88.

The St. Petersburg- USA Orphanage Research Team. 2005. Characteristics of children, caregivers, and orphanages for young children in St. Petersburg, Russian Federation. Journal of Applied Developmental Psychology 26:477-506. 10.1016/j.appdev.2005.06.002

The St. Petersburg- USA Orphanage Research Team. 2005. Characteristics of children, caregivers, and orphanages for young children in St. Petersburg, Russian Federation. Journal of Applied Developmental Psychology 26:477-506. 10.1016/j.appdev.2005.06.002

The World Bank Group. DataBank: Health Nutrition and Population Statistics. http://datatopics.worldbank.org/health/.

Theobald S, Morgan R, Hawkins K, Ssali S, George A, and Molyneux S. 2017. The importance of gender analysis in research for health systems strengthening. Health Policy Plan 32:v1-v3. 10.1093/heapol/czx163

UNICEF. 2017. Orphans. https://www.unicef.org/media/media_45279.html.

UNICEF. April 2019. Malnutrition. https://data.unicef.org/topic/nutrition/malnutrition/.

United Nations General Assembly. 2009. Guidelines for the Alternative Care of Children, UN document A/RES/64/142. Geneva: United Nations.

United Nations Human Rights Office of the High Commissioner. 1990. Convention on the Rights of the Child.

Whetten K, Ostermann J, Pence BW, Whetten RA, Messer LC, Ariely S, O'Donnell K, Wasonga AI, Vann V, Itemba D, Eticha M, Madan I, and Thielman NM. 2014. Three-year change in the wellbeing of orphaned 
531

532

533

534

535

536

537

538

539

540

541 and separated children in institutional and family-based care settings in five low- and middle-income countries. PLoS One 9:e104872. 10.1371/journal.pone.0104872

Whetten K, Ostermann J, Whetten RA, Pence BW, O'Donnell K, Messer LC, and Thielman NM. 2009. A comparison of the wellbeing of orphans and abandoned children ages 6-12 in institutional and communitybased care settings in 5 less wealthy nations. PLoS One 4:e8169. 10.1371/journal.pone.0008169

World Health Organization. 2019a. Growth reference data for 5-19 years. https://www.who.int/growthref/en/. World Health Organization. 2019b. The WHO Child Growth Standards. https://www.who.int/childgrowth/standards/en/.

Zahid MK, and Karim KMR. 2013. Nutritional status and dietary intake of the orphans: A case study in the ICH (Intervida Children Home) in Dhaka city in Bangladesh. Bangladesh Journal of Nutrition: 23-30.

10.3329/bjnut.v24i0.14034 
Figure 1

PRISMA flow diagram 


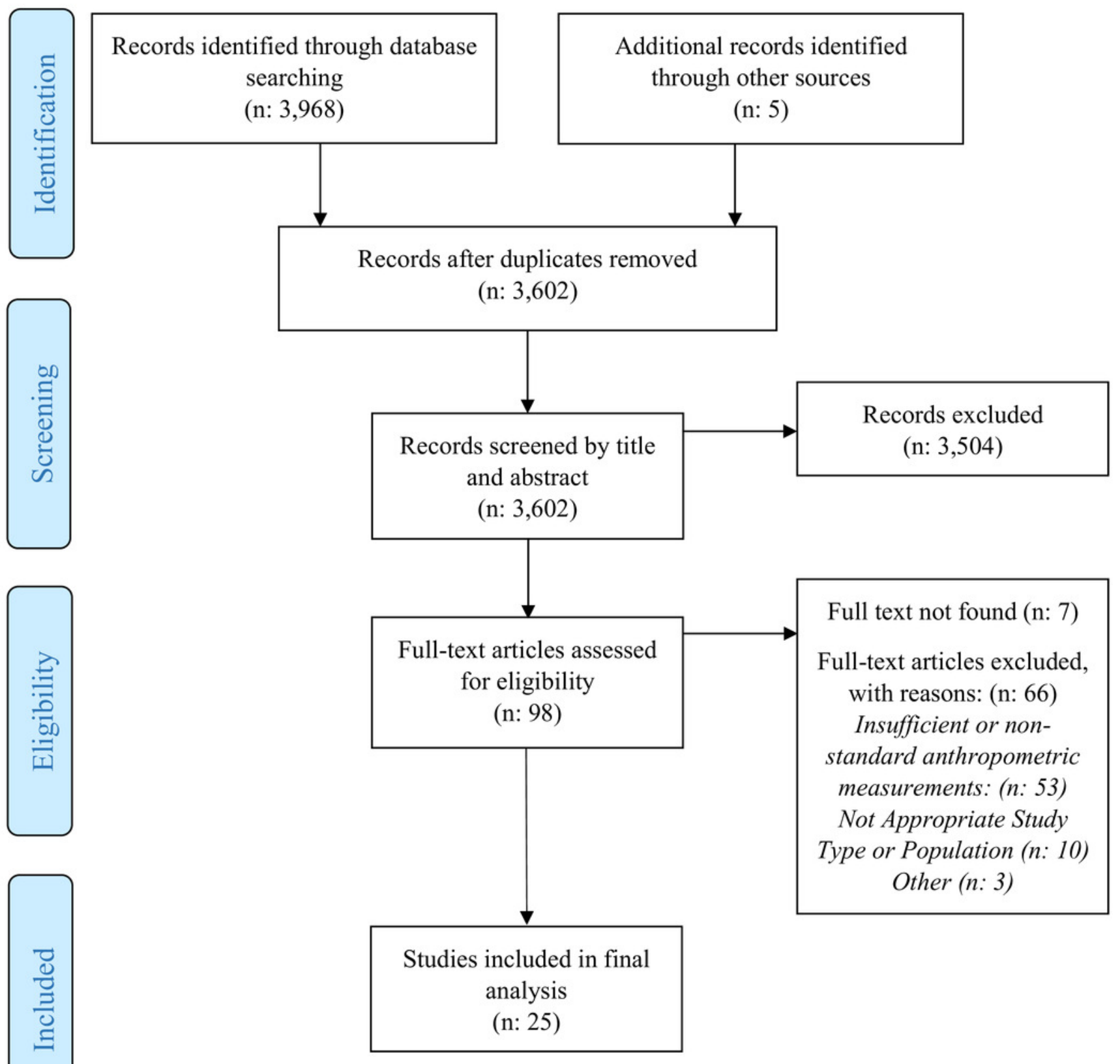




\section{Table $\mathbf{1}$ (on next page)}

Description of studies included in review.

Description of studies included in the review of children living within institutionalized care. 


\begin{tabular}{|c|c|c|c|c|c|}
\hline Author, Year & Study Design & Country & $\begin{array}{l}\text { Number of } \\
\text { Institutions }\end{array}$ & Study Population & $\begin{array}{l}\text { Gender (Percent } \\
\text { Female) }\end{array}$ \\
\hline \multicolumn{6}{|l|}{ Multi-Country } \\
\hline Whetten, 2014 & $\begin{array}{l}\text { Longitudinal } \\
\text { Cohort }\end{array}$ & $\begin{array}{l}\text { Cambodia, } \\
\text { Ethiopia, } \\
\text { India, Kenya, } \\
\text { Tanzania }\end{array}$ & 83 & $\begin{array}{l}\text { n: } 2,283, \text { IBC: } 993 \\
(43.5 \%) \text { and FBC: } \\
1,290(56.5 \%) \text {, median } \\
\text { age } 9 \text { years at baseline, } \\
\text { range } 6-12 \text { years and } \\
\text { median age } 12 \text { years at } \\
\text { year } 3 \text { follow-up, range } \\
8-16 \text { years }\end{array}$ & $\begin{array}{l}\text { IBC: } 43 \%, \text { FBC: } \\
47 \%\end{array}$ \\
\hline Whetten, 2009 & Cross Sectional & $\begin{array}{l}\text { Cambodia, } \\
\text { Ethiopia, } \\
\text { India, Kenya, } \\
\text { Tanzania }\end{array}$ & 83 & $\begin{array}{l}\mathrm{n}: 2,837, \text { IBC: } 1,480,6- \\
12 \text { years, mean age } 9 \\
\text { years, FBC: } 1,357\end{array}$ & $\begin{array}{l}\text { IBC: } 42.8 \%, \text { FBC: } \\
47.1 \%\end{array}$ \\
\hline \multicolumn{6}{|l|}{ Africa } \\
\hline Aboud, 1991 & $\begin{array}{l}\text { Cross } \\
\text { Sectional }\end{array}$ & Ethiopia & 1 & $\begin{array}{l}\mathrm{n}: 81,5-14 \text { years, } \mathrm{IBC} \\
\text { mean age } 9.5 \text { years } \pm \\
2.8, \text { FBC mean age } 9.7 \\
\pm 2.6\end{array}$ & $25.9 \%$ \\
\hline Braitstein, 2013 & Cross Sectional & Kenya & 19 & $\begin{array}{l}\text { n: } 2862, \text { IBC: } 1337, \\
\text { FBC: } 1425, \text { CLS: } 100, \\
\text { 0-18 years, median age } \\
11.1 \text { years }\end{array}$ & $46 \%$ \\
\hline Mwaniki, 2014 & Cross Sectional & Kenya & $\begin{array}{l}4 \text { Schools } \\
\text { (many } \\
\text { orphanages } \\
\text { fed into } \\
\text { them) }\end{array}$ & $\begin{array}{l}\text { n: } 416, \text { IBC: } 208, \\
\text { CC:208, range } 4-11 \\
\text { years, } 50 \% 4-7 \text { years } \\
\text { and } 50 \% 8-11 \text { years }\end{array}$ & $50 \%$ \\
\hline Panpanich, 1999 & Cross Sectional & Malawi & 3 & $\begin{array}{l}\text { n: } 293, \text { IBC: } 76, \text { mean } \\
\text { age } 6.44 \pm 4.69, \text { range } 0- \\
<15 \text { years, FBC: } 137, \\
\text { mean age } 7.92 \pm 2.62, \\
\text { CC: } 80, \text { mean age } \\
6.1 \pm 3.17\end{array}$ & $\begin{array}{l}\text { Total: } 45.4 \%, \text { IBC } \\
44.7 \%, \text { FBC: } 44.5^{\circ} \\
\text { CC: } 47.4 \%\end{array}$ \\
\hline \multicolumn{6}{|l|}{ Asia } \\
\hline bin Shaziman, 2017 & Cross Sectional & Malaysia & 5 & n: $85,13-18$ years & - \\
\hline Chowdhury, 2017 & Cross Sectional & Bangladesh & 1 & $\begin{array}{l}\mathrm{n}: 232,6-18 \text { years, } \\
\text { mean age } 13.38 \text { years } \pm \\
3.69\end{array}$ & $44 \%$ \\
\hline Hearst, 2014 & Cross Sectional & Kazakhstan & 10 & $\begin{array}{l}\text { n: } 308 \text { children, } 0-3 \\
\text { years }\end{array}$ & - \\
\hline Kapavarapu, 2012 & $\begin{array}{l}\text { Prospective } \\
\text { Longitudinal }\end{array}$ & India & 1 & $\begin{array}{l}\text { n: } 85, \text { mean age } 9.2 \\
\text { years, range } 4-14\end{array}$ & $40 \%$ \\
\hline Kroupina, 2014 & Cross Sectional & Kazakhstan & 6 & $\begin{array}{l}\mathrm{n}: 103 \text {, ages } 5-29 \\
\text { months, mean } 14.89 \\
\text { months } \pm 6.85)\end{array}$ & $49.5 \%$ \\
\hline
\end{tabular}




\begin{tabular}{|c|c|c|c|c|c|}
\hline Lewindon, 1997 & Cross Sectional & Hong Kong & 1 & $\begin{array}{l}\mathrm{n}: 215,11.9 \text { years } \pm 5.2 \\
\text { range } 1.9-27\end{array}$ & $47 \%$ \\
\hline Myint, 2012 & Cross Sectional & Myanmar & 1 & $\begin{array}{l}\text { n: } 60,2-15 \text { years, }>5: \\
26.7 \%, 5-10: 56.7 \% \text {, } \\
11-15: 16.6 \%\end{array}$ & $53.3 \%$ \\
\hline Sarma, 1999 & Cross Sectional & India & 70 & $3,822,6-18$ years & - \\
\hline Zahid, 2013 & Cross Sectional & Bangladesh & 1 & $\begin{array}{l}\mathrm{n}: 49,6-15 \text { years, mean } \\
\text { age } 8.72 \text { years } \pm 1.38\end{array}$ & $61 \%$ \\
\hline \multicolumn{6}{|l|}{ Eastern Europe } \\
\hline Lesho, 2002 & Cross Sectional & Moldova & - & n: 367 & - \\
\hline Miller, 2006 & Cross Sectional & Russia & 3 & $\begin{array}{l}\text { n: } 234, \text { mean age } 21 \\
\text { months } \pm 12.6, \text { range } 1.5 \\
\text { months to } 6 \text { years }\end{array}$ & $\begin{array}{l}45 \% \text { (gender not } \\
\text { recorded for } 12 \\
\text { children) }\end{array}$ \\
\hline $\begin{array}{l}\text { The St. Petersburg- } \\
\text { USA Orphanage } \\
\text { Research Team, } 2005\end{array}$ & Cross Sectional & Russia & 3 & $\begin{array}{l}\mathrm{n}: 325 \text { children, } 0-5 \\
\text { years }\end{array}$ & - \\
\hline \multicolumn{6}{|l|}{ European Union } \\
\hline Johnson, 2010 & Cross Sectional & Romania & 6 & $\begin{array}{l}\text { n: } 136, \text { mean age } 21 \\
\text { months } \pm 7.32 ; \text { range } 5 \\
\text { months- } 2.7 \text { years }\end{array}$ & $50 \%$ \\
\hline Martins, 2012 & $\begin{array}{l}\text { Prospective } \\
\text { Longitudinal }\end{array}$ & Portugal & 15 & $\begin{array}{l}\mathrm{n}: 49, \text { mean } 7.14 \\
\text { months } \pm 6.17) \text { range } 0- \\
21 \text { months }\end{array}$ & $49 \%$ \\
\hline Pysz, 2015 & Cross Sectional & Poland & 5 & $\mathrm{n}: 153$, range $7-20$ years & $43.8 \%$ \\
\hline Smyke, 2007 & Cross Sectional & Romania & 6 & $\begin{array}{l}\text { n: } 208, \text { IBC: } 123, \text { CC: } \\
66,5 \text { months }-2.6 \\
\text { years, mean age } 20.65 \\
\text { months } \pm 7.26\end{array}$ & $\begin{array}{l}\text { IBC: } 50.4 \% \\
\text { CC: } 53 \%\end{array}$ \\
\hline \multicolumn{6}{|l|}{ Middle East } \\
\hline El-Kassas, 2017 & Cross Sectional & Lebanon & 2 & $\begin{array}{l}\mathrm{n}: 153,5-14 \text { years, } \\
\text { mean age } 8.86 \pm 2.45 \\
\text { years }\end{array}$ & $62.7 \%$ \\
\hline \multicolumn{6}{|l|}{ South America } \\
\hline Nunes, 1999 & Cross Sectional & Brazil & 1 & n: 243, 1-15years & $30.3 \%$ \\
\hline
\end{tabular}




\begin{tabular}{|c|c|c|c|c|c|}
\hline \multicolumn{6}{|l|}{ The Caribbean } \\
\hline Nelson, 2016 & Cross Sectional & Jamaica & 3 & $\begin{array}{l}\text { n: } 226, \text { IBC n: } 113,5- \\
18 \text { years, mean } \\
10.66 \pm 3.67 \text { years, CC } \\
\text { n: } 103, \text { mean } 10.28 \\
\text { years } \pm 3.20\end{array}$ & $\begin{array}{l}\text { IBC: } 38.9 \%, \text { CC: } \\
58.3 \%\end{array}$ \\
\hline
\end{tabular}

Study population: IBC: Institution-based Care; FBC: Family-based Care (orphaned or abandoned children in community Community Children (non-orphans); CLS: Children living on the Street

2 
Table 2 (on next page)

Anthropometric measurements and results.

Anthropometric data of children living within institutionalized care in various countries. 


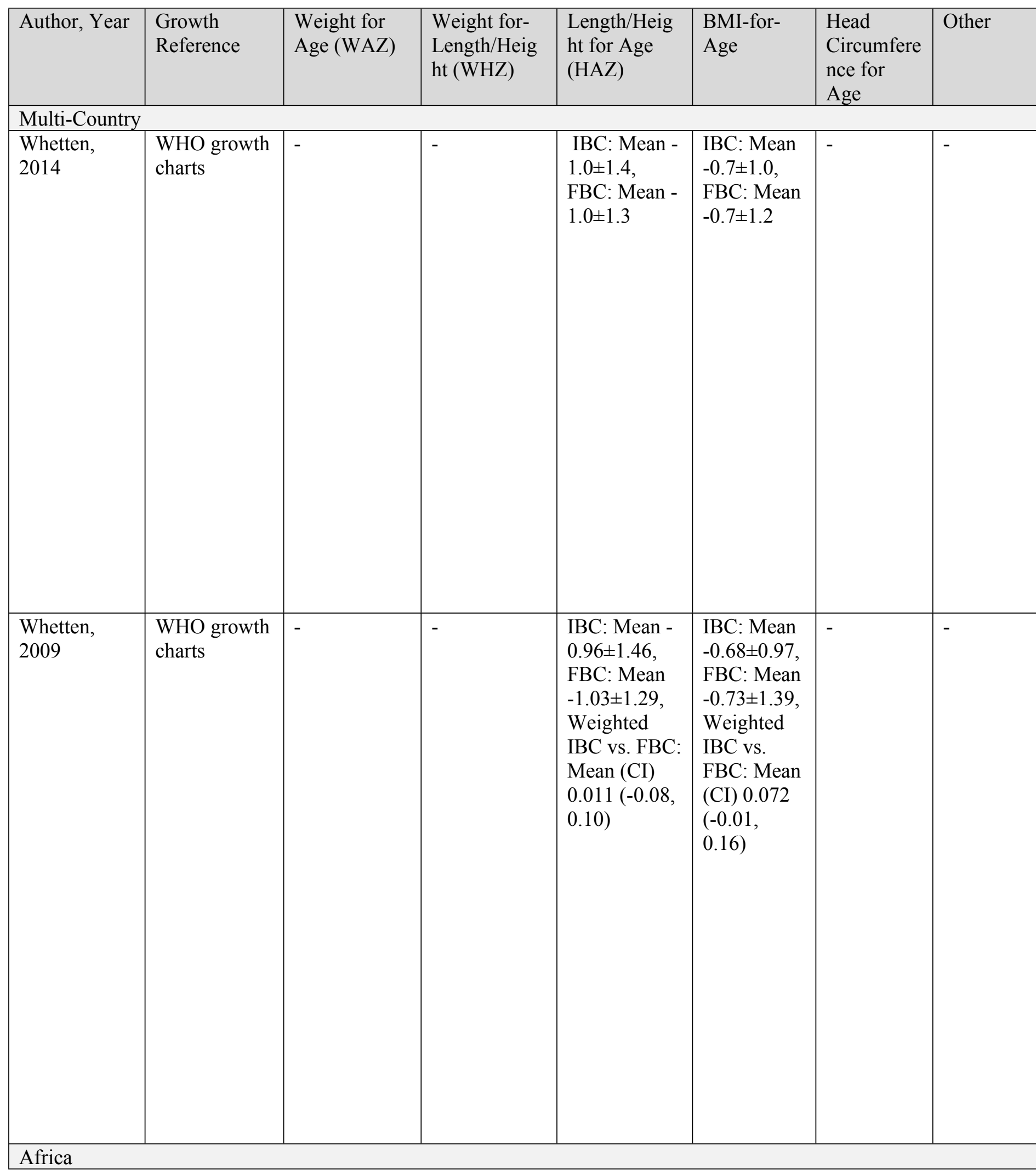




\begin{tabular}{|c|c|c|c|c|c|c|}
\hline Aboud, 1991 & NCHS & $\begin{array}{l}\text { IBC: } \\
>80 \%: 64 \% \\
<80 \%: 36 \% \\
\text { FBC: } \\
>80 \%: \\
73.5 \% \\
<80 \%: \\
25.6 \% \\
p=N S\end{array}$ & $\begin{array}{l}\text { IBC: } \\
>80 \%: \\
97.3 \% \\
<80 \%: 2.7 \% \\
\text { FBC: } \\
>80 \%: \\
95.6 \% \\
<80 \%: 4.1 \% \\
p=N S\end{array}$ & $\begin{array}{l}\text { IBC: } \\
>90 \%: 76 \% \\
<90 \%: 24 \% \\
\text { FBC: } \\
>90 \%: \\
91.8 \% \\
<90 \%: 8.2 \% \\
\text { p < } 0.05\end{array}$ & - & - \\
\hline $\begin{array}{l}\text { Braitstein, } \\
2013\end{array}$ & WHO & $\begin{array}{l}\leq 10 \text { years, } \mathrm{n}: \\
2131 \\
\geq-2 \text { z-scores } \\
\text { OR } \\
\text { unadjusted } \\
\text { IBC: } 1 \\
\text { FBC: } 0.87 \\
(0.56-1.34)\end{array}$ & $\begin{array}{l}\leq 5 \text { years, n: } \\
380 \\
\geq-2 \text { z-scores } \\
\text { OR } \\
\text { unadjusted } \\
\text { IBC: } 1 \\
\text { FBC: } 1.02 \\
(0.55-1.90)\end{array}$ & $\begin{array}{l}0-18 \text { years, n: } \\
2842 \\
\geq-2 \text { z-scores } \\
\text { OR } \\
\text { unadjusted } \\
\text { IBC: } 1 \\
\text { FBC: } 2.27 \\
(1.74-2.94) \\
\text { CLS: } 4.95 \\
(3.13-7.82) \\
\\
\text { \% Stunting } \\
\text { IBC: } 59 \% \\
\text { FBC: } 74 \% \\
\text { CLS: } 88 \%\end{array}$ & $\begin{array}{l}10-18 \\
\text { years, n: } \\
2374 \\
\geq-2 \text { z-scores } \\
\text { OR } \\
\text { unadjusted } \\
\text { IBC: } 1 \\
\text { FBC: } 0.70 \\
(0.49-1.01) \\
\text { CLS: } 0.58 \\
(0.31-1.08) \\
\\
\text { High BMI } \\
\text { (p <0.001) } \\
\text { IBC: } 10 \% \\
\text { FBC: } 16 \% \\
\text { CLS: } 19 \%\end{array}$ & - \\
\hline
\end{tabular}




\begin{tabular}{|c|c|c|c|c|c|c|c|}
\hline $\begin{array}{l}\text { Mwaniki, } \\
2014\end{array}$ & WHO 2006 & $\begin{array}{l}\text { IBC } \\
\text { n: } 69 \\
\% \\
\text { underweight: } \\
33.2 \% \\
\text { CC } \\
\text { n: } 31 \\
\% \\
\text { underweight: } \\
14.9 \% \\
\text { Total n: } 100 \\
\% \\
\text { underweight: } \\
24 \% \\
\text { p }>0.0001\end{array}$ & $\begin{array}{l}\text { IBC } \\
\text { n: } 19 \\
\% \text { wasted: } \\
9.2 \% \\
\text { CC } \\
\text { n: } 20 \\
\% \text { wasted: } \\
9.7 \% \\
\text { Total n: } 39 \\
\% \text { wasted: } \\
9.4 \% \\
\text { p=0.866 }\end{array}$ & $\begin{array}{l}\text { IBC } \\
\text { n: } 98 \\
\% \text { stunted: } \\
47.2 \% \\
\text { CC } \\
\text { n: } 51 \\
\% \text { stunted: } \\
24.5 \% \\
\text { Total n: } 149 \\
\% \text { stunted: } \\
35.8 \% \\
\text { p }>0.0001\end{array}$ & - & - & - \\
\hline $\begin{array}{l}\text { Panpanich, } \\
1999\end{array}$ & NCHS & $\begin{array}{l}<5 \text { years } \\
\text { Mean z- } \\
\text { scores: } \\
\text { IBC: - } \\
2.17 \pm 1.46 \\
\text { FBC: }- \\
1.82 \pm 1.19 \\
\text { CC: - } \\
1.37 \pm 1.28 \\
\text { Moderate } \\
\text { underweight } \\
\text { (<-2 z- } \\
\text { scores) } \%: \\
\text { IBC: } 54.8 \% \\
\text { FBC: } 33.3 \% \\
\text { CC: } 30 \% \\
\text { Severe } \\
\text { underweight } \\
\text { (<-3 z- } \\
\text { scores) \%: } \\
\text { IBC: } 38.7 \% \\
\text { FBC: } 16.7 \% \\
\text { CC: } 6.7 \% \\
\geq 5 \text { years } \\
\text { Mean z- } \\
\text { scores: } \\
\text { IBC: - } \\
0.91 \pm 0.96 \\
\text { FBC: - } \\
1.11 \pm 1.10 \\
\text { CC: - }\end{array}$ & $\begin{array}{l}<5 \text { years } \\
\text { Mean z- } \\
\text { scores: } \\
\text { IBC: - } \\
0.35 \pm 1.15 \\
\text { FBC: }- \\
0.68 \pm 1.10 \\
\text { CC: - } \\
0.45 \pm 0.93 \\
\text { Wasting (<-2 } \\
\text { z-scores) \%: } \\
\text { IBC: } 9 \% \\
\text { FBC: } 12 \% \\
\text { CC: } 0 \% \\
\geq 5 \text { years } \\
\text { Mean z- } \\
\text { scores: } \\
\text { IBC: - } \\
0.08 \pm 0.91 \\
\text { FBC: - } \\
0.64 \pm 0.99 \\
\text { CC: - } \\
0.53 \pm 0.79 \\
\text { p<0.05 for } \\
\text { variance } \\
\text { between the } \\
\text { three groups } \\
\text { Wasting ( }<-2 \\
\text { z-scores) } \% \text { : } \\
\text { IBC: } 0 \% \\
\text { FBC: } 5.3 \%\end{array}$ & $\begin{array}{l}<5 \text { years } \\
\text { Mean z- } \\
\text { scores: } \\
\text { IBC: - } \\
2.75 \pm 1.29 \\
\text { FBC: }- \\
2.20 \pm 1.51 \\
\text { CC: - } \\
1.61 \pm 1.57 \\
\text { p<0.05 for } \\
\text { variance } \\
\text { between the } \\
\text { three groups } \\
\text { Stunting (<-2 } \\
\text { Z-scores) } \%: \\
\text { IBC: } 64.5 \% \\
\text { FBC: } 50 \% \\
\text { CC: } 46.4 \% \\
\geq 5 \text { years } \\
\text { Mean z- } \\
\text { scores: } \\
\text { IBC: - } \\
1.07 \pm 1.51 \\
\text { FBC: }- \\
1.07 \pm 1.51 \\
\text { CC: }- \\
1.41 \pm 1.41 \\
\text { Stunting }(<-2 \\
\text { z-scores) } \%: \\
\text { IBC: } 9.1 \% \\
\text { FBC: } 30.4 \%\end{array}$ & - & - & - \\
\hline
\end{tabular}




\begin{tabular}{|c|c|c|c|c|c|c|}
\hline & & $\begin{array}{l}1.24 \pm 1.00 \\
\text { Moderate } \\
\text { underweight } \\
(<-2 \mathrm{z}- \\
\text { scores) } \% \text { : } \\
\text { IBC: } 6.8 \% \\
\text { FBC: } 23.9 \% \\
\text { CC: } 20.8 \%\end{array}$ & CC: $2.3 \%$ & CC: $34 \%$ & & \\
\hline \multicolumn{7}{|l|}{ Asia } \\
\hline $\begin{array}{l}\text { bin } \\
\text { Shaziman, } \\
2017\end{array}$ & $\begin{array}{l}\text { WHO } \\
\text { Growth } \\
\text { References }\end{array}$ & - & - & - & $\begin{array}{l}\text { Severely } \\
\text { thin } 4.7 \% \\
\text { Thin } 2.4 \% \\
\text { Normal } \\
61.2 \% \\
\text { Overweight } \\
16.5 \% \\
\text { Obesity } \\
15.3 \%\end{array}$ & - \\
\hline $\begin{array}{l}\text { Chowdhury, } \\
2017\end{array}$ & $\begin{array}{l}\text { WHO } \\
\text { Growth } \\
\text { References, } \\
\text { Essence of } \\
\text { Pediatrics } \\
2011 \text { ranges } \\
\text { for } \\
\text { malnutrition }\end{array}$ & $\begin{array}{l}\text { Total } \\
\text { malnourished } \\
\text { : } 60.3 \% \text {, } \\
\text { Mild: } 43.1 \% \text {, } \\
\text { Moderate: } \\
\text { 16.8\%, } \\
\text { Severe: } 0.4 \%\end{array}$ & - & - & - & - \\
\hline
\end{tabular}




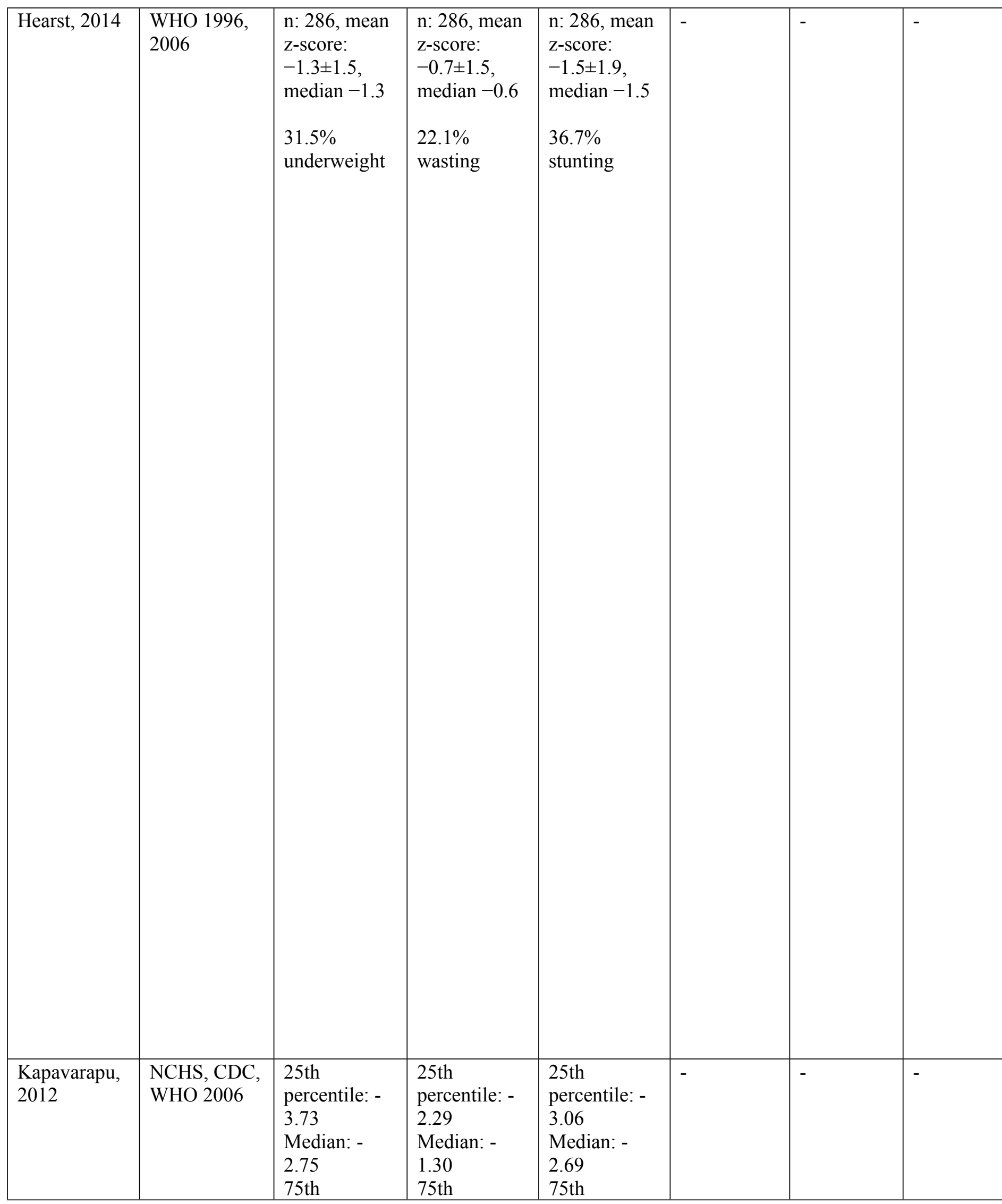




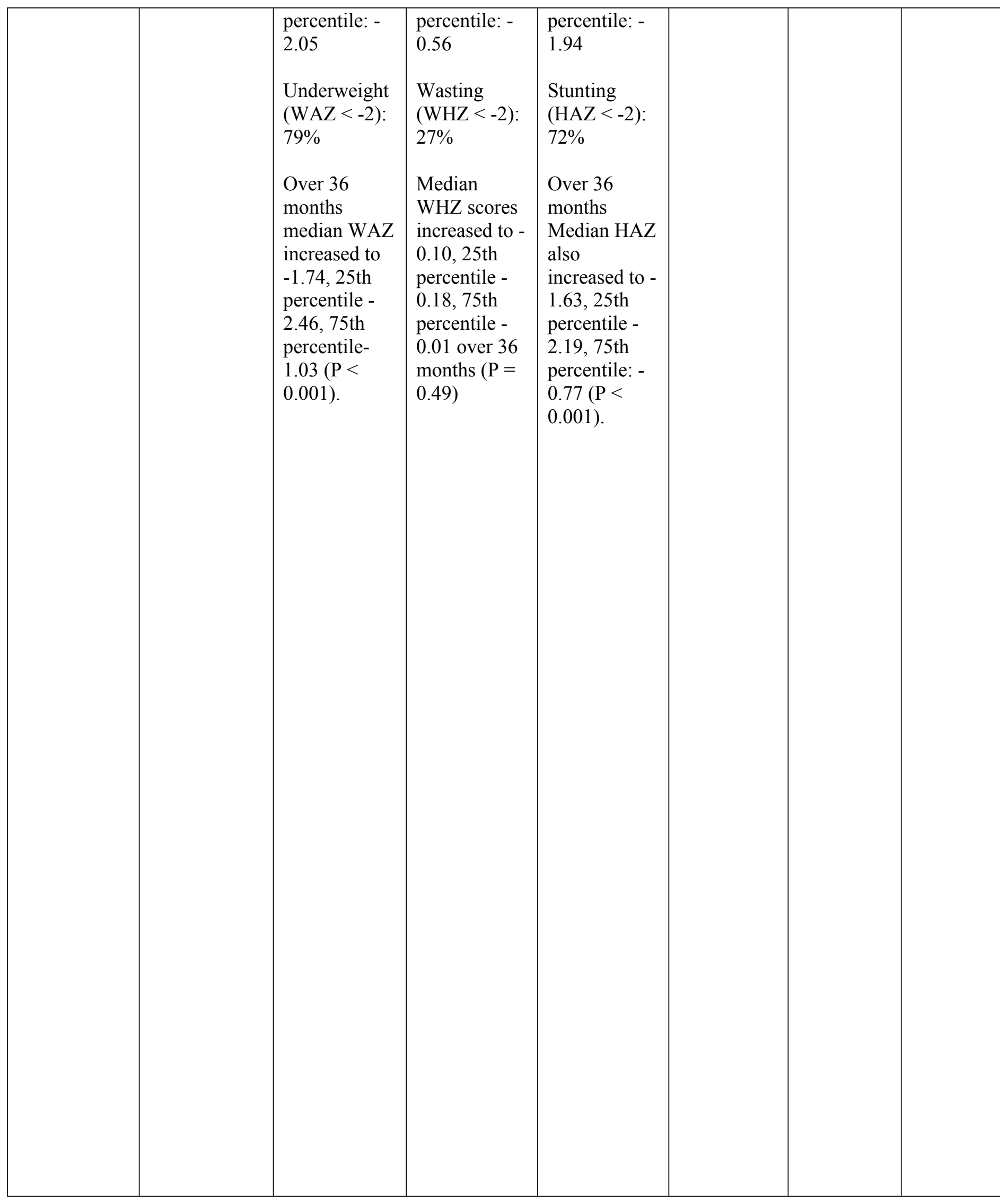




\begin{tabular}{|c|c|c|c|c|c|c|c|}
\hline $\begin{array}{l}\text { Kroupina, } \\
2014\end{array}$ & WHO 2006 & $\begin{array}{l}\text { Mean: - } \\
1.34 \pm 1.17 \text {, } \\
\text { range }-4.9 \text { to } \\
0.94 \\
<-2 \text { z-scores: } \\
22.3 \%\end{array}$ & $\begin{array}{l}\text { Mean: - } \\
0.63 \pm 1.41, \\
\text { range }-4.44 \\
\text { to } 2.84 \\
<-2 \text { z-scores: } \\
19.4 \%\end{array}$ & $\begin{array}{l}\text { Mean: - } \\
1.62 \pm 1.61 \\
\text { range }-5.49 \\
\text { to } 3.11 \\
<-2 \mathrm{z} \text {-scores: } \\
35.5 \%\end{array}$ & - & $\begin{array}{l}\mathrm{n}: 102, \\
\text { mean: - } \\
1.70 \pm 1.27, \\
\text { range }-4.53 \\
\text { to } 1.90 \\
<-2 \text { z- } \\
\text { scores: } \\
41.2 \%\end{array}$ & - \\
\hline $\begin{array}{l}\text { Lewindon, } \\
1997\end{array}$ & $\begin{array}{l}\text { Not specified } \\
\text { n:141 }\end{array}$ & $\begin{array}{l}\text { Mean: - } 3.9 \text { z- } \\
\text { scores }\end{array}$ & - & - & - & - & $\begin{array}{l}\text { Triceps } \\
\text { Skin Fold } \\
\text { Median: } \\
58.6 \%\end{array}$ \\
\hline Myint, 2012 & WHO & - & - & $\begin{array}{l}\text { Short } \\
\text { Stature: } \\
18.3 \% \\
\text { Stunted } 45 \%\end{array}$ & $\begin{array}{l}\text { Underweig } \\
\text { ht: } 26.7 \% \\
\text { Overweight } \\
: 8.3 \% \\
\text { Obese: } \\
1.7 \%\end{array}$ & - & - \\
\hline
\end{tabular}




\begin{tabular}{|c|c|c|c|c|c|c|c|}
\hline Sarma, 1999 & NCHS & $\begin{array}{l}\text { Girls mean } \\
\text { wt range } \\
(\mathrm{kg}): 16.5 \pm 2- \\
46.8 \pm 9.66 \\
\\
\text { Boys mean } \\
\text { wt range } \\
(\mathrm{kg}) \text { : } \\
16.3 \pm 2.18- \\
49.3 \pm 6.96\end{array}$ & - & $\begin{array}{l}\text { Girls mean ht } \\
\text { range }(\mathrm{cm}) \text { : } \\
104 \pm 6.30- \\
154.2 \pm 5.64 \\
\text { Boys mean } \\
\text { ht range } \\
(\mathrm{cm}): \\
106 \pm 6.52- \\
166.0 \pm 9.49\end{array}$ & - & - & $\begin{array}{l}\text { Girls mean } \\
\text { arm } \\
\text { circumfere } \\
\text { ce }(\mathrm{cm}) \text { : } \\
15 \pm 0.78 \text { - } \\
22.7 \pm 3.59 \\
\\
\text { Boys mean } \\
\text { arm } \\
\text { circumfere } \\
\text { ce }(\mathrm{cm}) \text { : } \\
14.5 \pm 1.04- \\
23.3 \pm 0.60\end{array}$ \\
\hline Zahid, 2013 & $\begin{array}{l}\text { Nutrition } \\
\text { survey of } \\
\text { Rural } \\
\text { Bangladesh } \\
1996\end{array}$ & $\begin{array}{l}\text { Mean: - } \\
0.39 \pm 1.22 \\
\text { Underweight: } \\
13 \% \\
\text { Normal: } \\
84.8 \% \\
\text { Overweight: } \\
2.2 \%\end{array}$ & $\begin{array}{l}\text { Mean: } \\
0.38 \pm 1.36 \\
\text { Wasted: } \\
2.7 \% \\
\text { Normal: } \\
83.8 \% \text {, } \\
\text { Overweight: } \\
8.1 \% \\
\text { Obese: } 5.4 \% \\
\end{array}$ & $\begin{array}{l}\text { Mean: - } \\
0.76 \pm 1.02 \\
\text { Stunted: } \\
8.7 \% \\
\text { Normal: } \\
89.1 \% \\
\text { Tall: } 2.2 \%\end{array}$ & $\begin{array}{l}\text { Underweig } \\
\text { ht: } 10.87 \% \\
\text { Normal: } \\
60.87 \% \\
\text { Overweight } \\
: 21.74 \% \\
\text { Obese: } \\
6.5 \%\end{array}$ & - & - \\
\hline \multicolumn{8}{|c|}{ Eastern Europe } \\
\hline Miller, 2006 & $\begin{array}{l}\text { WHO } \\
\text { (excluding } \\
\text { head } \\
\text { circumferenc } \\
\text { e which was } \\
\text { compared to } \\
\text { American } \\
\text { standards) } \\
\text { n: 201, mean } \\
\text { z-scores } \\
\text { (excluding } \\
\text { CWD) }\end{array}$ & $\begin{array}{l}\text { Birth: - } \\
1.34 \pm 0.08 \\
\text { Placement: - } \\
1.59 \pm 0.12 \\
\text { Present: - } \\
1.50 \pm 0.12\end{array}$ & - & $\begin{array}{l}\text { Birth: - } \\
.62 \pm .14 \\
\text { Placement: - } \\
1.45 \pm 0.13 \\
\text { Present: - } \\
1.48 \pm 0.10\end{array}$ & - & $\begin{array}{l}\text { Birth: - } \\
1.55 \pm 0.12 \\
\text { Placement: } \\
-1.38 \\
\pm 0.11 \\
\text { Present: - } \\
1.20 \pm 0.11\end{array}$ & - \\
\hline
\end{tabular}




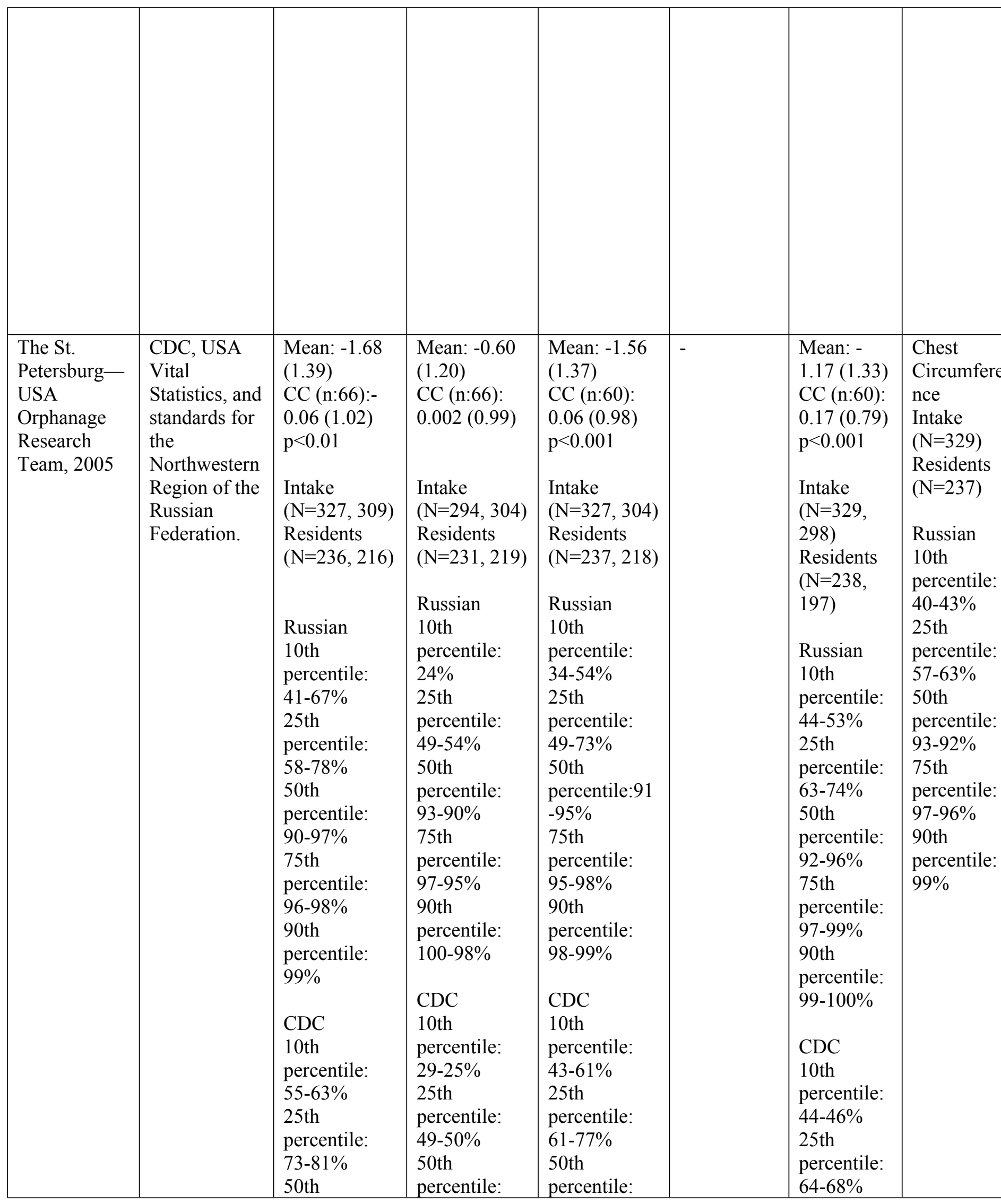




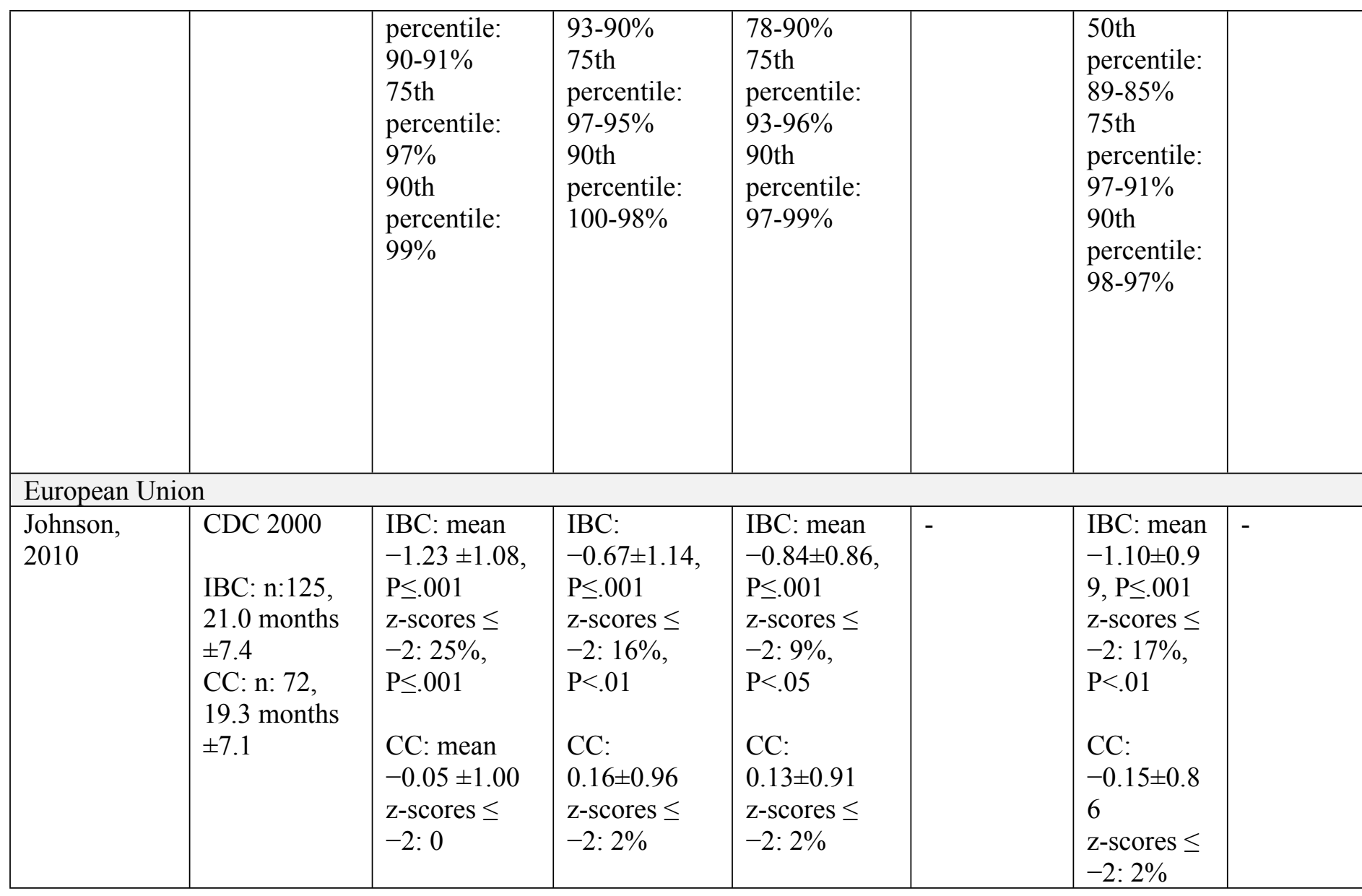




\begin{tabular}{|c|c|c|c|c|c|c|c|}
\hline $\begin{array}{l}\text { Martins, } \\
2012\end{array}$ & $\begin{array}{l}\text { WHO 2009, } \\
\text { Latent Class } \\
\text { Analysis } \\
\text { (LCA) } \\
\text { Mean, SD }\end{array}$ & $\begin{array}{l}\text { Persistently } \\
\text { low (n: } 10, \\
20.4 \% \text { ) } \\
\text { Percentile T0 } \\
\text { (admission): } \\
\text { 1.23 } \pm 1.60 \\
\text { Percentile } \\
\text { T1: } \\
\text { 3.91 } \pm 6.52 \\
\text { Percentile } \\
\text { T2: } \\
2.11 \pm 3.39 \\
\text { Percentile } \\
\text { T3: } \\
4.39 \pm 6.07 \\
\\
\text { Deteriorating } \\
\text { (n: } 12, \\
24.5 \% \text { ) } \\
\text { Percentile T0 } \\
\text { (admission): } \\
\text { 19.04 } \pm 28.63 \\
\text { Percentile } \\
\text { T1: } \\
\text { 20.85 } 23.25 \\
\text { Percentile } \\
\text { T2: } \\
\text { 15.48 } \pm 21.87 \\
\text { Percentile } \\
\text { T3: } 17.83 \\
\text { (18.47) } \\
\text { Improving } \\
\text { (n: } 16, \\
32.7 \% \text { ) } \\
\text { Percentile T0 } \\
\text { (admission): } \\
24.02 \pm 26.42 \\
\text { Percentile } \\
\text { T1: } \\
27.92 \pm 26.82 \\
\text { Percentile } \\
\text { T2: } \\
27.42 \pm 28.85 \\
\text { Percentile } \\
\text { T3: } \\
30.13 \pm 23.98 \\
\text { Persistently } \\
\text { high (n: } 11, \\
22.5 \% \text { ) }\end{array}$ & - & $\begin{array}{l}\text { Persistently } \\
\text { low (n: } 18, \\
36.7 \% \text { ) } \\
\text { Percentile T0 } \\
\text { (admission): } \\
3.17 \pm 4.47 \\
\text { Percentile } \\
\text { T1: } \\
\text { 4.52 } \pm 5.24 \\
\text { Percentile } \\
\text { T2: } \\
2.32 \pm 2.67 \\
\text { Percentile } \\
\text { T3: 4.56 } \\
\pm 4.39 \\
\\
\text { Deteriorating } \\
\text { (n: } 9,18.4 \% \text { ) } \\
\text { Percentile T0 } \\
\text { (admission): } \\
\text { 44.51 } \pm 27.02 \\
\text { Percentile } \\
\text { T1: } \\
49.52 \pm 12.37 \\
\text { Percentile } \\
\text { T2: } \\
21.44 \pm 9.64 \\
\text { Percentile } \\
\text { T3: } \\
23.83 \pm 15.70 \\
\text { Improving } \\
\text { (n: } 14, \\
28.6 \% \text { ) } \\
\text { Percentile T0 } \\
\text { (admission): } \\
\text { 15.00 } \pm 10.00 \\
\text { Percentile } \\
\text { T1: } \\
18.17 \pm 11.54 \\
\text { Percentile } \\
\text { T2: } \\
29.14 \pm 26.88 \\
\text { Percentile } \\
\text { T3: } \\
32.47 \pm 12.18 \\
\text { Persistently } \\
\text { high (n: } 8, \\
\text { 16.3\%) } \\
\text { Percentile T0 }\end{array}$ & - & $\begin{array}{l}\text { Persistentl } \\
\text { y low (n: } \\
\text { 11, 22.5\%) } \\
\text { Percentile } \\
\text { T0 } \\
\text { (admission } \\
\text { ): } \\
5.92 \pm 6.72 \\
\text { Percentile } \\
\text { T1: } \\
6.13 \pm 6.35 \\
\text { Percentile } \\
\text { T2: } \\
10.05 \pm 8.55 \\
\text { Percentile } \\
\text { T3: } \\
14.62 \pm 13.7 \\
9 \\
\text { Deteriorati } \\
\text { ng (n: } 9 \text {, } \\
18.4 \% \text { ) } \\
\text { Percentile } \\
\text { T0 } \\
\text { (admission } \\
\text { ): } \\
34.43 \pm 29.0 \\
0 \\
\text { Percentile } \\
\text { T1: } \\
42.92 \pm 29.1 \\
4 \\
\text { Percentile } \\
\text { T2: } \\
37.79 \pm 28.2 \\
1 \\
\text { Percentile } \\
\text { T3: } \\
18.02 \pm 14.3 \\
5 \\
\text { Improving } \\
\text { (n: } 16, \\
32.7 \%) \\
\text { Percentile } \\
\text { T0 } \\
\text { (admission } \\
\text { ): } \\
40.42 \pm 26.7 \\
5 \\
\text { Percentile }\end{array}$ & - \\
\hline
\end{tabular}




\begin{tabular}{|c|c|c|c|c|c|c|}
\hline & & 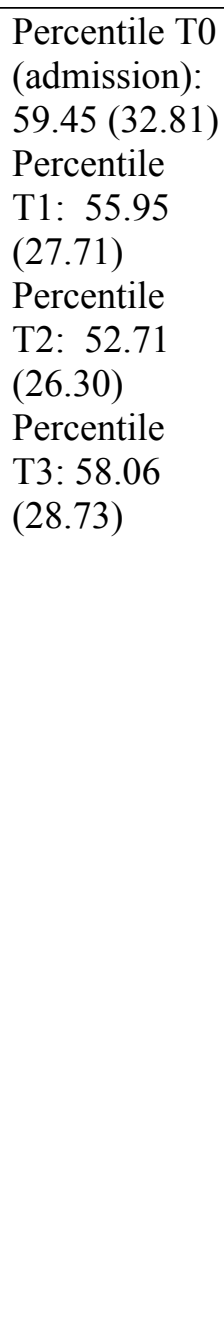 & \begin{tabular}{l|l} 
(admission): \\
$76.41 \pm 32.50$ \\
Percentile \\
T1: \\
$71.26 \pm 29.18$ \\
Percentile \\
T2: \\
$72.82 \pm 14.49$ \\
Percentile \\
T3: \\
$78.42 \pm 20.35$
\end{tabular} & & $\begin{array}{l}\text { T1: } \\
55.36 \pm 24.5 \\
6 \\
\text { Percentile } \\
\text { T2: } \\
60.50 \pm 12.8 \\
4 \\
\text { Percentile } \\
\text { T3: } \\
66.05 \pm 15.1 \\
0 \\
\text { Persistentl } \\
\text { y high (n: } \\
13,26.5 \%) \\
\text { Percentile } \\
\text { T0 } \\
\text { (admission } \\
\text { ): } \\
68.93 \pm 24.3 \\
9 \\
\text { Percentile } \\
\text { T1: } \\
90.05 \pm 8.58 \\
\text { Percentile } \\
\text { T2: } \\
89.58 \pm 9.33 \\
\text { Percentile } \\
\text { T3: } \\
91.18 \pm 7.89\end{array}$ & \\
\hline Pysz, 2015 & $\begin{array}{l}\text { University of } \\
\text { Physical } \\
\text { Education in } \\
\text { Krakow } \\
\text { (percentiles) }\end{array}$ & - & $\mid-$ & $\begin{array}{l}\text { Thinness or } \\
\text { Underweig } \\
\text { ht: } 14 \% \\
\text { boys and } \\
5 \% \text { girls } \\
\text { Normal } \\
\text { BMI: } 86 \% \\
\text { boys and } \\
92 \% \text { girls } \\
\text { Overweight } \\
\text { or obesity: } \\
6 \% \text { boys } \\
\text { and } 6 \% \\
\text { girls }\end{array}$ & - & $\begin{array}{l}\text { Thickness } \\
\text { of the sum } \\
\text { of three } \\
\text { skin folds } \\
\text { normal } \\
\text { ranges: } \\
\text { boys } 83 \% \\
\text { and girls } \\
85 \%\end{array}$ \\
\hline
\end{tabular}




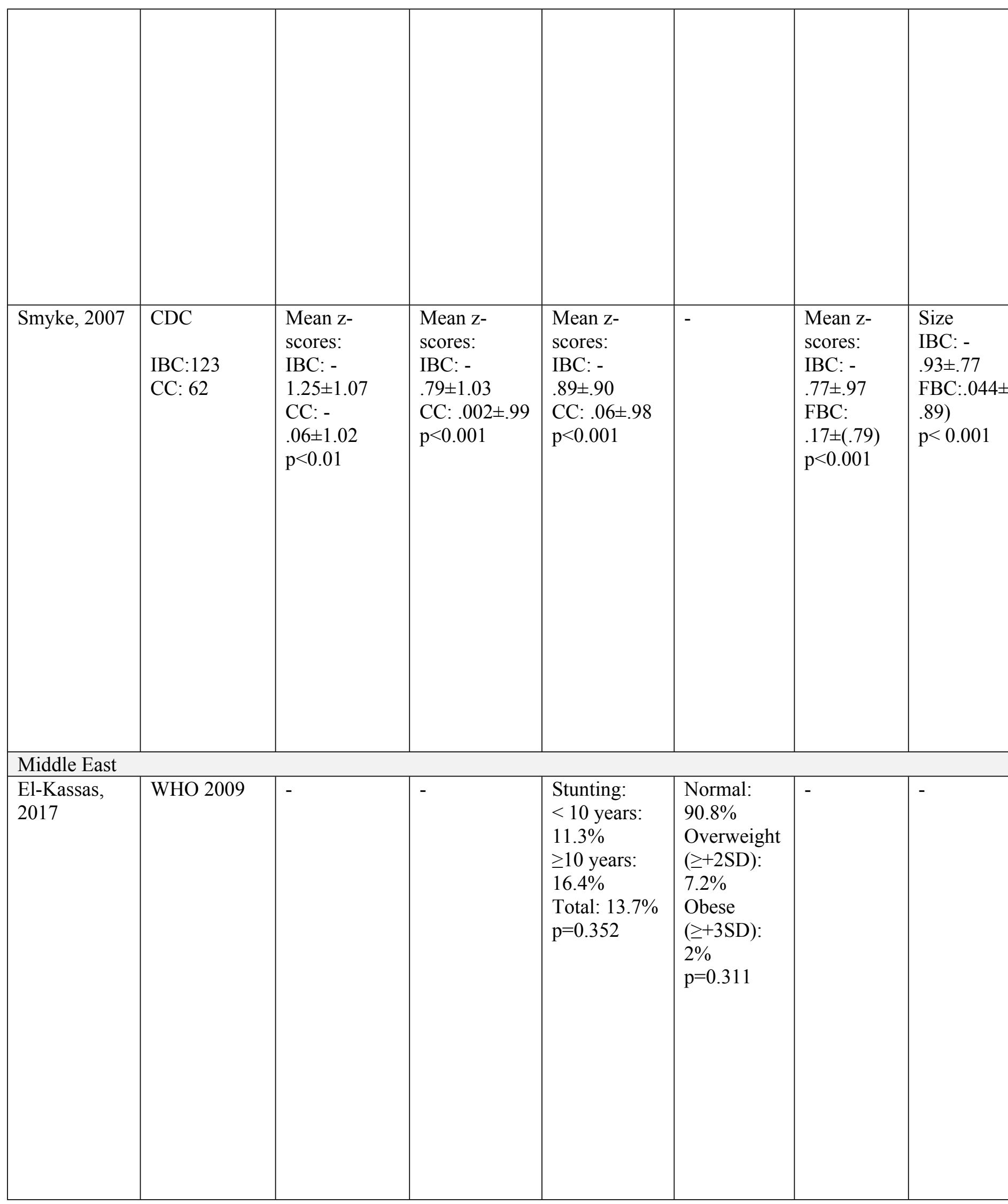




\begin{tabular}{|c|c|c|c|c|c|c|c|}
\hline \multicolumn{8}{|l|}{ South America } \\
\hline Nunes, 1999 & $\begin{array}{l}\text { NCHS, type } \\
\text { classified } \\
\text { according to } \\
\text { the Seone- } \\
\text { Lathan } \\
\text { classification }\end{array}$ & - & - & - & - & - & - \\
\hline \multicolumn{8}{|l|}{ The Caribbean } \\
\hline Nelson, 2016 & WHO & $\begin{array}{l}\text { IBC Girls } \\
5-11 \text { years (n: } \\
24): \\
0.006 \pm 0.748 \\
\text { IBC Boys } \\
5-11 \text { years (n: } \\
38):- \\
0.229 \pm 1.09 \\
20 \% \text { of IBC } \\
\text { were mildly } \\
\text { underweight, } \\
\text { and } 2.5 \% \\
\text { were } \\
\text { moderately } \\
\text { underweight. }\end{array}$ & - & $\begin{array}{l}\text { IBC Girls } \\
5-11 \text { years } \\
\text { (n: } 24 \text { ): } \\
0.509 \pm 1.21 \\
12-18 \text { years } \\
\text { (n: } 20 \text { ): } \\
0.065 \pm 0.962 \\
\text { IBC Boys } \\
5-11 \text { years } \\
\text { (n: } 33 \text { ): - } \\
0.239 \pm 1.29 \\
12-18 \text { years } \\
\text { (n: } 10 \text { ): } \\
0.991 \pm 2.57 \\
\\
15.3 \% \text { of } \\
\text { IBC were }\end{array}$ & - & - & $\begin{array}{l}\text { Mean } \\
\text { MUAC } \\
\text { IBC Girls } \\
5-11 \text { years } \\
\text { (n: } 24) \text { : } \\
18.08 \mathrm{~cm} \pm 2 \\
0 \\
12-18 \text { year } \\
\text { (n: } 20) \\
22.55 \mathrm{~cm} \\
\pm 2.87 \\
\text { IBC Boys } \\
5-11 \text { years } \\
\text { (n: } 38) \text { : } \\
17.35 \mathrm{~cm} \\
\pm 3.8 \\
12-18 \text { year }\end{array}$ \\
\hline
\end{tabular}




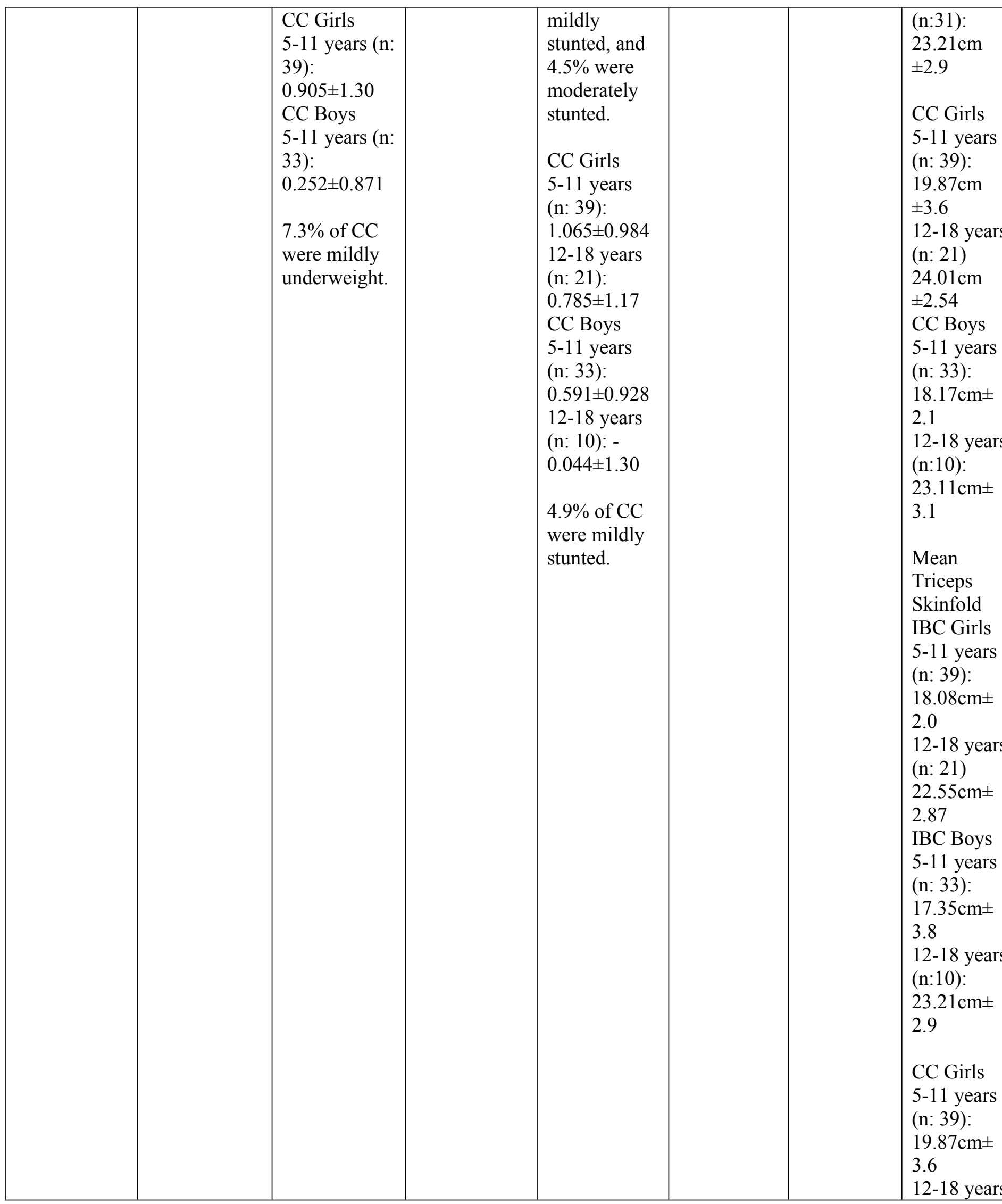




\begin{tabular}{|l|l|l|l|l|l|}
\hline & & & & $(\mathrm{n}: 21)$ \\
$24.01 \mathrm{~cm} \pm$ \\
2.54 \\
\end{tabular}

Study population: IBC: Institution-based Care; FBC: Family-based Care (orphaned or abandoned children in community Community Children (non-orphans); CLS: Children living on the Street

Anthropometric Measurement Method abbreviations: WHO: World Health Organization; NCHS: National Center for Hea CDC: Centers for Disease Control (USA); BMI: Body Mass Index; ht: height, wt: weight; MUAC: Mid-pper Arm Circun 


\section{Table 3 (on next page)}

Diet, micronutrient status, clinical signs/ symptoms and infections results.

Diet, micronutrient status, clinical signs/ symptoms and infections of children living within institutionalized care in various countries. 


\begin{tabular}{|c|c|c|c|}
\hline $\begin{array}{l}\text { Author, } \\
\text { Year }\end{array}$ & Dietary Analysis & Micronutrient Status & Clinical Signs/ Sympto \\
\hline \multicolumn{4}{|c|}{ Multi-Country } \\
\hline $\begin{array}{l}\text { Whetten, } \\
2009\end{array}$ & - & - & $\begin{array}{l}\text { By caregiver report, ins } \\
\text { were also less likely to } \\
\text { diarrhea or fever in the } \\
\text { interview ( } 19.9 \text { vs. } 41.2 \\
220.6 \%, 95 \% \text { CI [224\% } \\
\text { on the day of the interv } \\
\text { weighted difference } 26 \text {. } \\
24 \%]) \text {. }\end{array}$ \\
\hline \multicolumn{4}{|l|}{ Africa } \\
\hline Aboud, 1991 & - & - & $\begin{array}{l}\text { Edema: IBC (4\%), FBC } \\
\text { Conjunctival Pallor: IB } \\
\text { Xerophthalmia: IBC (1) } \\
\text { Goiter: IBC }(2.7 \%), \text { FB } \\
\text { Nutritional problems w } \\
\text { more prevalent among }\end{array}$ \\
\hline $\begin{array}{l}\text { Braitstein, } \\
2013\end{array}$ & $\begin{array}{l}\text { Using the Household Food Insecurity } \\
\text { Access Scale (HFIAS), } 42 \% \text { of IBC and } \\
2 \% \text { of FBC reported being food secure. } \\
95 \% \text { of children in IBC reported an } \\
\text { adequate diet compared to } 93 \% \text { of children } \\
\text { in FBC and } 99 \% \text { of SLC, }(p=0.009) \text {. }\end{array}$ & - & $\begin{array}{l}\text { HIV rates: IBC }(2.1 \%), \\
(1 \%)(p=0.001)\end{array}$ \\
\hline $\begin{array}{l}\text { Mwaniki, } \\
2014\end{array}$ & $\begin{array}{l}\text { Using a } 24 \mathrm{hr} \text { diet recall and Nutri Survey } \\
\text { program, diets were assessed. A total of } 63 \\
\text { and } 37 \text { food items were consumed by the } \\
\text { CC and IBC respectively. Only } 7.2 \% \text { of } \\
\text { IBC consumed more than three food groups } \\
\text { compared to } 45.2 \% \text { of CC. } 92.9 \% \text { of IBC } \\
\text { and } 54.8 \% \text { of CC consumed less than four } \\
\text { food groups ( }<0.05 \text { ). CC had significantly } \\
\text { ( }<<0.05 \text { ) higher diversity of foods served } \\
\text { than IBC. } \\
\text { Energy intake: The total mean energy } \\
\text { intake among CC was } 1,890 \text { Kcal per day } \\
\text { and was significantly higher ( }<0.05 \text { ) than } \\
\text { that of IBC. The intake of energy by IBC } \\
\text { who took lunch was } 1,547 \text { Kcal compared } \\
\text { to the energy intake of CC who also took } \\
\text { the three meals of the day ( }<<0.05 \text { ). The } \\
\text { mean energy intake of IBC who did not } \\
\text { take lunch was less than half of that of CC. } \\
\text { IBC who attended school away from the } \\
\text { orphanage had two meals (mainly breakfast } \\
\text { and supper) in a day during school days }\end{array}$ & - & $\begin{array}{l}\text { IBC } \\
\text { Diarrhea: } 11.5 \% \\
\text { Cough/ colds: } 12.5 \% \\
\text { Fever: } 1.4 \% \\
\text { Vomiting/skin rashes: } 7 \\
\text { FBC } \\
\text { Diarrhea: } 2.4 \% \text { ( } \mathrm{p}=0.0 \\
\text { Cough/colds: } 2.9 \%(\mathrm{p}= \\
\text { Fever: } 0.5 \%(\mathrm{p}=0.8) \\
\text { Vomiting/skin rashes: } 0 \\
\text { Prevalence of morbidity } \\
\text { ( } \mathrm{p}<0.05) \text { higher among } \\
\text { CC children and } 1.2 \text { tim } \\
\text { sick. IBC had significar } \\
\text { prevalence of diarrhea } \\
\text { compared to CC. } \\
\text { IBC were twice less lik } \\
\text { critical times compared } \\
\text { reported washing hands } \\
\text { the day before the inter }\end{array}$ \\
\hline
\end{tabular}




\begin{tabular}{|c|c|c|c|}
\hline & $\begin{array}{l}\text { and three meals during the weekend and } \\
\text { did not meet their daily needs compared to } \\
\text { CC who always had three meals. } \\
\text { IBC had } 3.9 \text { times higher risk of consuming } \\
\text { inadequate calories compared to CC. } \\
\text { Orphanages tend toward exclusive reliance } \\
\text { on starches and legumes. Food in } \\
\text { orphanages mainly depended on donations. }\end{array}$ & & $\begin{array}{l}78.2 \% \text { of CC. } 49.4 \% \text { of } \\
\text { washed their hands bef } \\
\text { also a higher proportion } \\
\text { reported washing hands } \\
\text { critical times compared } \\
\text { (p<0.01). Vaccination a } \\
\text { to } \mathrm{CC}(\mathrm{p}<0.05) .\end{array}$ \\
\hline $\begin{array}{l}\text { Panpanich, } \\
1999\end{array}$ & - & - & $\begin{array}{l}\text { Illness in past four wee } \\
\text { IBC: } 35 \% \\
\text { FBC: } 37 \% \\
\text { CC: } 51 \% \\
\text { Undernutrition was pre } \\
\text { who had a history of ill } \\
\text { compared with } 18.8 \% \\
\text { no illness ( }<<0.05) \\
\text { HIV rates: IBC } 23 \%\end{array}$ \\
\hline \multicolumn{4}{|l|}{ Asia } \\
\hline Hearst, 2014 & - & $\begin{array}{l}\text { The nutritional status, based on } \\
\text { blood biomarkers, revealed that } \\
37.1 \% \text { of the children were } \\
\text { anemic, } 21.4 \% \text { had low albumin, } \\
38.1 \% \text { had low vitamin } \mathrm{D}, 5.5 \% \\
\text { were iodine-deficient and } 2 \% \\
\text { had low serum zinc. }\end{array}$ & - \\
\hline $\begin{array}{l}\text { Kapavarapu, } \\
2012\end{array}$ & $\begin{array}{l}\text { Dietary intake was compared with the } \\
\text { Indian Recommended Dietary Allowance } \\
\text { (RDA). A } 24 \text {-h dietary recall revealed that } \\
\text { children }<7 \text { years received } 75 \% \text { of the RDA } \\
\text { for energy, and older children received } 93 \\
\text { to } 107 \% \text { of RDA for energy. All children } \\
\text { received adequate ( }>100 \% \text { RDA) amounts } \\
\text { of both protein and fat. }\end{array}$ & $\begin{array}{l}\text { Hemoglobin }(\mathrm{Hb}) \text { level was } \\
\text { measured using automated blood } \\
\text { analyzer. Results indicated that } \\
\text { anemia was a prominent } \\
\text { manifestation of HIV. Although } \\
\text { baseline prevalence of anemia } \\
\text { was only } 40 \% \text {, during the study } \\
\text { period the cumulative incidence } \\
\text { rose to } 85 \% \text {. }\end{array}$ & $\begin{array}{l}75 \% \text { had infections in tl } \\
\text { months) of admission ir } \\
\text { Pulmonary tuberculosis } \\
\text { Impetigo: } 31 \% \\
\text { Varicella zoster: } 24 \% \\
\text { Chronic suppurative oti } \\
\text { Parotitis: } 13 \% \\
\text { HIV Group Home }\end{array}$ \\
\hline $\begin{array}{l}\text { Kroupina, } \\
2014\end{array}$ & - & $\begin{array}{l}\text { Venous blood samples were } \\
\text { used for assessment of } \\
\text { hemoglobin status. Anemia } \\
\text { status was not found to be } \\
\text { predictive of development } \\
\text { status. } \\
\text { "A significant percentage of the } \\
\text { children in Kazakh institutions } \\
\text { have micronutrient deficiencies; } \\
\text { most strikingly, over half the } \\
\text { sample was found to be anemic." }\end{array}$ & - \\
\hline
\end{tabular}




\begin{tabular}{|c|c|c|c|}
\hline $\begin{array}{l}\text { Lewindon } \\
1997\end{array}$ & - & - & $\begin{array}{l}\text { Disabled children in lor } \\
\text { increased risk for H. py } \\
\text { were seropositive for } \mathrm{H} \\
\text { pediatric patients }(<16 \mathrm{y} \\
\text { compared with } 50 \text { contr } \\
(\mathrm{p}>0.0002) \text {. Children } \mathrm{w} \\
\text { frequently have excessi } \\
\text { with saliva could be an } \\
\text { transmission of } \mathrm{H} \text {. plyo }\end{array}$ \\
\hline Myint, 2012 & - & - & $\begin{array}{l}\text { Ocular manifestations: } \\
\text { Systemic comorbidities } \\
\text { Chronic otitis media: } 2 \\
\text { Pulmonary tuberculosis } \\
\text { HIV Group Home }\end{array}$ \\
\hline Sarma, 1999 & $\begin{array}{l}\text { Dietary intake was compared with the } \\
\text { Indian Council of Medical Research's } \\
\text { (1984) recommended dietary allowance } \\
\text { (RDA). 1,150 children were selected for } \\
\text { dietary analysis. Energy intakes fell short } \\
\text { compared to the RDA for most children } \\
\text { and the deficit was higher in older children } \\
\text { when compared to younger children. }\end{array}$ & $\begin{array}{l}\text { Most common nutritional } \\
\text { deficiencies encountered: } \\
\text { vitamin A ( } 2-8.5 \%) \text {, vitamin B } \\
\text { complex and anemia. }\end{array}$ & $\begin{array}{l}\text { Pallor indicating anemi } \\
\text { Phyrnoderma: } 1.2-6.8 \% \\
\text { Angular stomatitis: } 1-3 \\
\text { Dental mottling: } 1-18 \% \\
\text { Dental decay: } 1-22 \% \\
\text { Cough, cold, fever, diar } \\
\text { skin, eyes and ear/nose/ } \\
\text { most common. Deficier } \\
\text { were more common in }\end{array}$ \\
\hline Zahid, 2013 & $\begin{array}{l}\text { Food intake was obtained by } 24 \text { hour food- } \\
\text { weighing method for seven days. The } \\
\text { average food intake were calculated by } \\
\text { using the Institute of Nutrition and Food } \\
\text { Science. Total food intake was about } \\
\text { double the intake of similar children in the } \\
1995-96 \text { nutrition survey. Mean energy } \\
(2,270 \text { kcal), protein ( } 65 \text { grams), } \\
\text { carbohydrate ( } 335 \text { grams) and fat intake } \\
\text { ( } 73 \text { grams). Carbohydrates, protein and fat } \\
\text { provide } 59 \%, 12 \% \text { and } 29 \% \text { of total } \\
\text { calories respectively. Protein intake was } 65 \\
\text { grams, about } 50 \% \text { higher than the } \\
\text { requirement and the } 1995-96 \text { nutrition } \\
\text { survey of the urban location of the same } \\
\text { group. Energy intake was found } 20 \% \\
\text { higher than requirement and about } 42 \% \\
\text { higher compared to } 1995-96 \text { nutrition } \\
\text { survey. } \\
\text { Average intake of IBC was higher than the } \\
\text { national intake and the nutritional status of } \\
\text { IBC was also found to be better than the } \\
\text { national average by any nutritional criteria. } \\
\text { Studies consider this to be potentially }\end{array}$ & $\begin{array}{l}\text { Mean intake calcium } 826 \mathrm{mg} \text {, } \\
\text { iron } 31 \mathrm{mg} \text {, vitamin A } 6,462 \mathrm{IU} \text {, } \\
\text { carotene } 10,508 \mu \mathrm{g} \text {, vitamin B1 } \\
1.60 \mathrm{mg} \text {, vitamin B2 } 1.64 \mathrm{mg} \text {, } \\
\text { niacin } 19 \mathrm{mg} \text {, vitamin C } 111 \mathrm{mg} \\
\text { and zinc } 10.2 \mathrm{mg} . \\
\text { "Compared to } 1995-96 \text { nutrition } \\
\text { survey, IBC had significantly } \\
\text { higher micronutrient intake." }\end{array}$ & - \\
\hline
\end{tabular}




\begin{tabular}{|c|c|c|c|}
\hline & $\begin{array}{l}\text { attributed to better health and care system } \\
\text { prevailing in the orphanage apart provision } \\
\text { of high-calorie and protein-rich food and } \\
\text { that the nutritional status IBC, who are } \\
\text { nutritionally disadvantageous, can be } \\
\text { improved through organized feeding and } \\
\text { better hygienic conditions. }\end{array}$ & & \\
\hline \multicolumn{4}{|c|}{ Eastern Europe } \\
\hline Lesho, 2002 & - & $\begin{array}{l}90 \% \text { of children had anemia and } \\
\text { one-fourth had severe anemia. }\end{array}$ & $\begin{array}{l}76 \% \text { of children had pa } \\
\text { infected with three or } \mathrm{m} \\
\text { Disease frequency: } \\
\text { Dermatologic: } 17 \% \\
\text { Respiratory: } 5 \% \\
\text { Genitourinary disorders } \\
\text { Ear, nose and throat: } 4 \% \\
\text { Psychiatric: } 3 \%\end{array}$ \\
\hline \multicolumn{4}{|c|}{ European Union } \\
\hline Pysz, 2015 & $\begin{array}{l}\text { Diets were chemically analyzed using the } \\
\text { Kjeldahl method and Soxhlet method and } \\
\text { compared to Polish Estimated Average } \\
\text { Requirements. Results indicate that daily } \\
\text { diets meet about } 80 \% \text { of recommended } \\
\text { intake of energy, fat and carbohydrates. } \\
\text { The intake of protein with daily diets } \\
\text { exceeded EAR value and ranged from } 115 \\
\text { to } 362 \% \text { (average } 214.2 \% \text { ). It has been also } \\
\text { found that the intake of basic nutrients was } \\
\text { varied, coefficient variation (CV) ranged } \\
\text { from } 22.2 \% \text { to } 27.1 \% \text {. } \\
\text { Boys, compared to girls, spent almost twice } \\
\text { as much time on physical activity. }\end{array}$ & - & - \\
\hline
\end{tabular}




\begin{tabular}{|c|c|c|c|}
\hline $\begin{array}{l}\text { El-Kassas, } \\
2017\end{array}$ & $\begin{array}{l}\text { Compared to the Dietary Guidelines for } \\
\text { American Children and Adolescents } 2015 \\
\text { and based on a semi-quantitative food } \\
\text { frequency questionnaire, more than half } \\
\text { were estimated to have inadequate daily } \\
\text { intake of vegetables, fruit, and proteins } \\
\text { compared to the recommendation. } \\
94.8 \% \text { consumed three meals per day. } \\
20.5 \% \text { of adolescents ( } \geq 10 \text { years) reported } \\
\text { meals did not satisfy appetite, compared to } \\
\text { only } 13 \% \text { of children below } 10 \text { years, with } \\
\text { no statistical significance between the two } \\
\text { groups (p = } 0.480 \text { ). } 45.1 \% \text { of the studied } \\
\text { sample revealed consumption of one snack } \\
\text { per day; } 49 \% \text { consumed sweet and } 19 \% \\
\text { consumed salty snacks on a regular basis. } \\
82 \% \text { of both age groups reported regular } \\
\text { intake of breakfast. } \\
\text { Inadequate protein intake (OR: } 0.017,95 \% \\
\text { CI: } 0.001-0.291 \text { ) was associated with } \\
\text { statistically significant lower odds for being } \\
\text { overweight and obese. Conversely, } \\
\text { consumption of sweet snacks (OR: } 6.492 \text {, } \\
95 \% \text { CI: } 1.124-37.512 \text { ) was associated } \\
\text { with significantly higher odds for } \\
\text { overweight and obesity. }\end{array}$ & - & $\begin{array}{l}\text { Abnormal Hair Conditi } \\
\text { Abnormal Skin Conditi } \\
\text { Muscle Wasting: } 2.6 \% \\
\text { Edema: } 0 \% \\
\text { Bowing of legs or knoc } \\
0.622 \text { ) } \\
\text { Abnormal Mucus Mem } \\
0.014) \\
\text { "Physical signs suggest } \\
\text { deficiencies were detec } \\
\text { sample." }\end{array}$ \\
\hline \multicolumn{4}{|c|}{ South America } \\
\hline Nunes, 1999 & - & Anemia: $3 \%$ & $\begin{array}{l}\text { "High rates of infectiou } \\
\text { children." } \\
\text { HIV: } 9.4 \% \\
\text { Gastroesophageal reflux } \\
\text { Parasites: } 6 \% \\
\text { Skin infections: } 10 \% \\
\text { Upper respiratory infect } \\
\text { Conjunctivitis: } 1.7 \%\end{array}$ \\
\hline
\end{tabular}




\begin{tabular}{|l|l|l|l}
\hline Nelson, & $\begin{array}{l}\text { Children living in both residential settings } \\
\text { listed (1) carbohydrates and starches, (2) } \\
\text { meat and (3) fruits and vegetables as the } \\
\text { most commonly consumed food items. } \\
\text { Significant difference in self-reports of } \\
\text { foods consumed most often by CC and IBC } \\
\text { (X2 }(4, \mathrm{~N}=215)=21.93, \mathrm{P}>0.000) \text {. CC were } \\
\text { more likely than IBC to report meat as } \\
\text { most often consumed food. Chi-square } \\
\text { analyses revealed no significant differences } \\
\text { in self-reports of foods consumed most } \\
\text { often by IBC in the three orphanages. No } \\
\text { significant differences in the food served at } \\
\text { the three orphanages. }\end{array}$ & \\
& $\begin{array}{l}\text { No difference between physical activity } \\
\text { between IBC and CC or between } \\
\text { orphanages. }\end{array}$ & \\
\hline
\end{tabular}

Study population: IBC: Institution-based Care; FBC: Family-based Care (orphaned or abandoned children in community Community Children (non-orphans); CLS: Children living on the Street 